\title{
Athens Journal of Mass Media and Communications
}

Quarterly Academic Periodical, Volume 8, Issue 1, January 2022

VRL: https://www.athensjournals.gr/ajmmc Email: journals@atiner.gr e-ISSN: 2407-9480 DOI: 10.30958 /ajmmc



Front Pages

\section{BUTLER CAIN}

"Silly and Superficial": Headline Tone in Press TV and Voice of America Coverage of the U.S. Withdrawal from the Joint

Comprehensive Plan of Action

\section{AHMED DEEN \& PO-LIN PAN}

Using Smartphone as a Journalistic Tool:

An Examination of Ethical Codes in Mobile Journalism in Saudi $\underline{\text { Arabia }}$

\section{Ayşe Aslı Sezgin}

Investigation of Social Approaches in Different Countries towards Suicide of the Blue Whale Game through Newspaper $\underline{\text { News }}$

\section{AYO OSISANWO}

"This Virus is a Common Threat to All Humans": Discourse $\underline{\text { Representation of COVID-19 in Selected Newspaper Editorials }}$ 


\section{Athens Journal of Mass Media and Communications}

Published by the Athens Institute for Education and Research (ATINER)

\section{Editors}

1. Dr. John Pavlik, Head, Mass Media and Communication Unit, ATINER \& Professor, Journalism and Media Studies, School of Communication and Information, Rutgers University, USA.

2. Dr. Patrick Vyncke, Professor of Communication Management, Department of Communication Sciences, Ghent University, Belgium.

Editorial \& Reviewers' Board

https://www.athensjournals.gr/ajmmc/eb

\section{Administration of the Journal}

1. Vice President of Publications: Dr Zoe Boutsioli

2. General Managing Editor of all ATINER's Publications: Ms. Afrodete Papanikou

3. ICT Managing Editor of all ATINER's Publications: Mr. Kostas Spyropoulos

4. Managing Editor of this Journal: Ms. Eirini Lentzou

ATINER is an Athens-based World Association of Academics and Researchers based in Athens. ATINER is an independent and non-profit Association with a Mission to become a forum where Academics and Researchers from all over the world can meet in Athens, exchange ideas on their research and discuss future developments in their disciplines, as well as engage with professionals from other fields. Athens was chosen because of its long history of academic gatherings, which go back thousands of years to Plato's Academy and Aristotle's Lyceum. Both these historic places are within walking distance from ATINER's downtown offices. Since antiquity, Athens was an open city. In the words of Pericles, Athens"...is open to the world, we never expel a foreigner from learning or seeing". ("Pericles' Funeral Oration", in Thucydides, The History of the Peloponnesian War). It is ATINER's mission to revive the glory of Ancient Athens by inviting the World Academic Community to the city, to learn from each other in an environment of freedom and respect for other people's opinions and beliefs. After all, the free expression of one's opinion formed the basis for the development of democracy, and Athens was its cradle. As it turned out, the Golden Age of Athens was in fact, the Golden Age of the Western Civilization. Education and (Re)searching for the 'truth' are the pillars of any free (democratic) society. This is the reason why Education and Research are the two core words in ATINER's name.

$* * * * * * * * * * * * * * * * * * * * * * * * * * * * * * * * * * * * * * * * * * * * * * * * * * * * * * * * * * * * * * * * * * * * * * * * * * * * * * * * * * * * * * * * * * * * * * *$

The Athens Journal of Mass Media and Communications (AJMMC) is an Open Access quarterly double-blind peer reviewed journal and considers papers from all areas from mass media and communication. The Journal encourages the submission of works that engages issues of international scope and that explore matters of theoretical importance across a diverse range of topics from journalism, to strategic communication, to economics, public policy, politics and technological change as they relate to media and society. Many of the papers published in this journal have been presented at the various conferences sponsored by the Mass Media \& Communication Unit of the Athens Institute for Education and Research (ATINER). All papers are subject to ATINER's Publication Ethical Policy and Statement. 
The Athens Journal of Mass Media and

Communications

ISSN NUMBER: 2407-9677 - DOI: 10.30958/ajmmc

Volume 8, Issue 1, January 2022

Download the entire issue ( $\underline{\mathrm{PDF}})$

Front Pages

i-viii

"Silly and Superficial": Headline Tone in Press TV

9

and Voice of America Coverage of the U.S.

Withdrawal from the Joint Comprehensive Plan of

$\underline{\text { Action }}$

Butler Cain

Using Smartphone as a Journalistic Tool:

An Examination of Ethical Codes in Mobile Journalism in Saudi Arabia

Ahmed Deen \& Po-Lin Pan

Investigation of Social Approaches in Different

Countries towards Suicide of the Blue Whale Game through Newspaper News

Ayşe Ash Sezgin

"This Virus is a Common Threat to All Humans":

Discourse Representation of COVID-19 in Selected

Newspaper Editorials

Ayo Osisanwo 


\section{The Athens Journal of Mass Media and Communications Editorial and Reviewers' Board}

$\underline{\text { Editors }}$

- Dr. John Pavlik, Head, Mass Media and Communication Unit, ATINER \& Professor, Journalism and Media Studies, School of Communication and Information, Rutgers University, USA.

- Dr. Patrick Vyncke, Professor of Communication Management, Department of Communication Sciences, Ghent University, Belgium.

\section{Editorial Board}

- Dr. John Pavlik, Head, Mass Media and Communication Unit, ATINER \& Professor, Rutgers University, USA.

- Dr. Burak Dogu, Academic Member, ATINER \& Vice Dean, Izmir University of Economics, Turkey.

- Dr. Andzela Armoniene, Head of The Fund Young Researcher, Lithuania.

- Dr. Mariam Gersamia, Professor \& Head, Division of Journalism and Mass Communication, Ivane Javakhishvili Tbilisi State University, Georgia.

- Dr. Egle Jaskuniene, Associate Professor \& Vice Dean for Research, Faculty of Creative Industries, Vilnius Gediminas Technical University, Lithuania.

- Dr. Berrin Yanikkaya, Academic Member, ATINER and Professor \& Head, School of Communication Studies, Auckland University of Technology, New Zealand.

- Dr. Dali Osepashvili, Professor, Department of Journalism and Mass Communication, Ivane Javakhishvili Tbilisi State University, Georgia.

- Dr. Walter Wymer, Academic Member, ATINER \& Professor of Marketing, University of Lethbridge, Canada.

- Dr. Alan Albarran, Academic Member, ATINER \& Professor, The University of North Texas, USA.

- Dr. Patricia L. Dooley, Elliott Distinguished Professor of Communication, Wichita State University, USA.

- Dr. Catherine Ann Collins, Professor, Department of Rhetoric, Willamette University, USA.

- Dr. Pamela Doyle Tran, Professor of Electronic News, University of Alabama, USA.

- Dr. S. Andrews, Professor, Department of Information Technology, Mahendra Engineering College, India.

- Dr. Emmanuel Ngwainmbi, Department of Communication Studies, The University of North Carolina, USA.

- Dr. Zsolt Alfred Polgar, Academic Member, ATINER \& Associate Professor, Technical University of Cluj-Napoca, Romania.

- Dr. Margaret M. Cassidy, Academic Member, ATINER \& Associate 
Professor, Adelphi University, USA.

- Dr. Baris Coban, Associate Professor, Communication Sciences Department, Dogus University, Turkey.

- Dr. Ulas Basar Gezgin, Associate Professor of Applied Communication, British University Vietnam, Vietnam.

- Dr. Anya Luscombe, Associate Professor and Head, Department of Academic Core, University College Roosevelt, The Netherlands.

- Dr. Charles Obot, Academic Member, ATINER \& Associate Professor, University of Uyo, Nigeria.

- Dr. Ceren Sozeri, Associate Professor, Faculty of Communication, Galatasaray University, Turkey.

- Dr. Matthew D. Matsaganis, Assistant Professor, Department of Communication, State University of New York (SUNY), USA.

- Dr. Geneviève A. Bonin, Assistant Professor, University of Ottawa, Canada.

- Dr. Klarissa Lueg, Assistant Professor, Aarhus University, Denmark.

- Dr. George Pavlou, Assistant Professor, European University, Cyprus.

- Dr. Yolandi Slabbert, Senior Lecturer, Department of Communication Science, University of South Africa, South Africa.

- Dr. Daniel Binns, Academic Member, ATINER \& Lecturer, RMIT University, Australia.

- Dr. Binoy Kampmark, Lecturer in Social Sciences, School of Global, Urban and Social Studies, RMIT University, Australia.

- Dr. Sarah Sparke, Academic Member, ATINER \& Research Associate, CMIR, University of the West of England, UK.

- Dr. Vittoria Sacco, Postdoctoral Assistant, Neuchatel University, Switzerland.

- Ms. Mania Alehpour, PhD Candidate, University of Tehran, Iran.

- General Managing Editor of all ATINER's Publications: Ms. Afrodete Papanikou

- ICT Managing Editor of all ATINER's Publications: Mr. Kostas Spyropoulos

- Managing Editor of this Journal: Ms. Olga Gkounta ( $\underline{\text { bio }}$ )

\section{Reviewers' Board}

Click Here 


\section{President's Message}

All ATINER's publications including its e-journals are open access without any costs (submission, processing, publishing, open access paid by authors, open access paid by readers etc.) and is independent of presentations at any of the many small events (conferences, symposiums, forums, colloquiums, courses, roundtable discussions) organized by ATINER throughout the year and entail significant costs of participating. The intellectual property rights of the submitting papers remain with the author. Before you submit, please make sure your paper meets the basic academic standards, which includes proper English. Some articles will be selected from the numerous papers that have been presented at the various annual international academic conferences organized by the different divisions and units of the Athens Institute for Education and Research. The plethora of papers presented every year will enable the editorial board of each journal to select the best, and in so doing produce a top-quality academic journal. In addition to papers presented, ATINER will encourage the independent submission of papers to be evaluated for publication.

The current issue is the first of the eighth volume of the Athens Journal of Mass Media and Communications (AJMMC), published by the Mass Media \& Communication Unit of ATINER.

Gregory T. Papanikos

President

ATINER 


\section{Athens Institute for Education and Research}

\section{A World Association of Academics and Researchers}

\section{Annual International Conference on Communication and Mass Media, 9-12 May 2022, Athens, Greece}

The Mass Media \& Communication Unit of ATINER organizes its 20 ${ }^{\text {th }}$ Annual International Conference on Communication and Mass Media, 9-12 May 2022, Athens, Greece sponsored by the Athens Journal of Mass Media and Communications. The aim of the conference is to bring together academics and researchers of Communications, Mass Media and other related disciplines. Please submit a proposal using the form available (https://www.atiner.gr/2022/FORM-MED.doc).

- Abstract Submission: 17 January 2022

- Acceptance of Abstract: 4 Weeks after Submission

- Submission of Paper: 11 April 2022

\section{Academic Members Responsible for the Conference}

- Dr. John Pavlik, Head, Mass Media and Communication Research Unit, ATINER \& Professor, Rutgers University, USA.

\section{Social and Educational Program}

The Social Program Emphasizes the Educational Aspect of the Academic Meetings of Atiner.

- Greek Night Entertainment (This is the official dinner of the conference)

- Athens Sightseeing: Old and New-An Educational Urban Walk

- Social Dinner

- Mycenae Visit

- Exploration of the Aegean Islands

- Delphi Visit

- Ancient Corinth and Cape Sounion

\section{Conference Fees}

Conference fees vary from $400 €$ to $2000 €$

Details can be found at: https://www.atiner.gr/2019fees 







\title{
"Silly and Superficial": Headline Tone in Press TV and Voice of America Coverage of the U.S. Withdrawal from the Joint Comprehensive Plan of Action
}

\begin{abstract}
By Butler Cain ${ }^{*}$
On May 8, 2018, U.S. President Donald Trump announced the United States would withdraw from the Joint Comprehensive Plan of Action (JCPOA) with Iran. President Trump had campaigned on removing the U.S. from the nuclear agreement, but the announcement still caught Iran and other parties to the JCPOA by surprise. This research analyzed three days of JCPOA-related news headlines from two international broadcasters: Press TV, headquartered in Tehran, and Voice of America, located in Washington, D.C. The majority of headlines published by both news organizations exhibited negative tone. Considering that reading a headline often substitutes for reading an entire news report, examining the headlines these international broadcasters used to present this event to their global audiences is a worthwhile pursuit.
\end{abstract}

Keywords: Iran, United States, nuclear, headline, tone

\section{Introduction}

U.S. President Donald Trump announced on May 8, 2018, the United States would withdraw from the Joint Comprehensive Plan of Action (JCPOA) with Iran (Landler, 2018). Known informally as the Iran nuclear deal, Iran had reached an agreement in July 2015 with a group of nations including the United States, the United Kingdom, France, Germany, China, and Russia to "significantly limit Tehran's nuclear ability for more than a decade in return for lifting international oil and financial sanctions" (Gordon and Sanger, 2015). Former President Barack Obama was able to get the agreement through Congress "without the support of a single member of the [Republican] party" (Steinhauer, 2015). Less than three years later, however, President Trump announced he was fulfilling a campaign promise to dissolve the agreement and re-impose sanctions against Iran (Landler, 2018).

\section{Rationale}

The announcement received news media coverage around the world. The United States' international broadcasting service, Voice of America, produced reports for its global audience and published updates on its website. Likewise, Press TV, Iran's international news network, reported on the breaking news story

\footnotetext{
"Chair and Professor, Department of Communications, University of North Alabama, USA.
} 
and published updates on its website. By writing their own news headlines or choosing to publish ones written by other news organizations, each global broadcasting service used headlines to frame the issue and establish the tone of news reports for their respective audiences. This analysis examines news headline tone in the reports published by Voice of America and Press TV regarding the United States' announced withdrawal from the Joint Comprehensive Plan of Action. Headlines were classified as exhibiting negative, positive, or neutral tone.

\section{Literature Review}

\section{Iran's Nuclear Program}

U.S. President Dwight Eisenhower delivered his "Atoms for Peace" speech before the U.N. General Assembly in December 1953 (Rowberry, 2013). Through this program, the United States committed to provide "research reactors, fuel and scientific training to developing countries wanting civilian nuclear programs" (Rowberry, 2013). Recipient states promised to use the technology and training "for peaceful, civilian purposes" (Rowberry, 2013). Iran was a participant in the initiative and started its nuclear program in 1957. After a decade of development, the United States helped Iran establish a nuclear research reactor and gave Iran the uranium to fuel it (Rowberry, 2013).

The Iranian Revolution of 1979 severed diplomatic ties between the United States and Iran, and it ended nuclear cooperation between the countries (Masterson, 2020). Through the 1990s and early 2000s, Iran's nuclear program continued development, and in April 2006, Iran announced it had enriched uranium for the first time (Masterson, 2020). Two months later, the United States, United Kingdom, France, Russia, China, and Germany (known as the P5+1, referring to the U.N. Security Council's five permanent members plus Germany) proposed an incentives package to convince Iran to stop its enrichment program (Masterson, 2020). Iran rejected the restrictions on its enrichment activities, and in December 2006, the United Nations Security Council imposed sanctions on Iran (Masterson, 2020). During the next several years, Iran continued expanding its nuclear program and the U.N. continued passing additional sanctions against the country.

A new era began in 2012 when the P5+1 and Iran initiated a series of negotiations to reach an agreement that would address U.N., U.S., and European Union security concerns while allowing Iran to continue its nuclear program without sanctions (Masterson, 2020). Three years later, on July 14, 2015, the P5+1 and Iran finalized the JCPOA agreement ("The Joint," 2018). The United Nations Security Council endorsed it on July 20, it was formally adopted on October 18, and the JCPOA was officially implemented on January 16, 2016 ("The Joint," 2018). Iran agreed to maintain restrictions on its nuclear activities and allow program monitoring and compliance verification by the International Atomic Energy Agency (Laub and Robinson, 2020). In exchange, the United Nations, the United States, and the European Union suspended or repealed sanctions against Iran (Laub and Robinson, 2020). 
During his 2016 U.S. presidential election campaign, Republican nominee Donald Trump promised to withdraw from the JCPOA if elected. He won election in November that year, and on October 13, 2017, President Trump announced he would not recertify the Iran nuclear deal ("Key moments," 2020). He followed through on that commitment when he announced on May 8, 2018, that the U.S. would withdraw from the JCPOA ("Key moments," 2020). Iran accused the United States of breaking its promises and criticized Europe for bowing to U.S. unilateralism (Laub and Robinson, 2020). Iran announced it would no longer honor its commitments "as long as the other parties to the JCPOA were in breach of theirs" (Laub and Robinson, 2020).

\section{Journalistic Tone}

News media headlines can serve both an agenda-setting and framing function. Sheafer (2007) noted that recent analyses of the mass media's agenda-setting function have focused more on the news media's role in telling audiences how to think about news events rather than simply which events to think about. Entman (2007) observed that the way information is framed can lead an audience to a particular conclusion and affect the audience's perception of how important a certain idea may be. Headlines attract the most visual attention from first-time page viewers (Leckner, 2012, p. 169). Additionally, they create a shortcut that provides a brief synopsis of the news report's contents (Andrew, 2007, p. 28). However, reading headlines to obtain "a quick and loose news update" invites risk of misinterpretation, and a headline alone may not accurately reflect the accompanying report's full contents (Ifantidou, 2009, p. 702). Still, headlines provide an opportunity to explore how people perceive issues of public importance and how readers' attitudes about those issues may be influenced (Nisar and Bleich, 2020, p. 6). Because readers often do not examine full news reports and choose instead to scan headlines (Dor, 2003, p. 718), it is important to consider headline tone in journalistic reports about international events. Therefore, this paper asks the following:

RQ: How many headlines from Press TV and Voice of America exhibit negative, positive, and neutral tone regarding President Trump's announcement to withdraw the United States from the Joint Comprehensive Plan of Action with Iran?

\section{Methodology}

This study is a descriptive content analysis of 75 news headlines appearing on the Press TV and Voice of America websites after President Trump announced the U.S. withdrawal from the JCPOA. The time frame for these reports is Tuesday, May 8, through Thursday, May 10, which represents news coverage from the day of the announcement plus two additional 24-hour news cycles. Press TV was chosen for examination because it is based in Tehran and its stated mission is to provide perspectives that are "often neglected" in the Western-dominated global media system ("About PressTV," 2017). As the international English-language 
service of Islamic Republic of Iran Broadcasting, Press TV coverage is presumed to reflect the views of Iran's leadership (Behravesh, 2013). Voice of America was chosen for examination because it is the United States' largest international broadcaster ("Mission and Values," n.d.). Its stated mission is to "present the policies of the United States clearly and effectively" while maintaining editorial independence as part of the U.S. Agency for Global Media ("Mission and Values," n.d.). Press TV and Voice of America also were chosen because they are government-supported information organizations located in their respective national capitals, Tehran and Washington, D.C. Finally, each broadcaster produces content for a global audience in English, which is the author's native language.

To identify news reports specific to the United States' withdrawal from the Iran nuclear deal, the author searched for the terms "Iran" and "nuclear" on the Voice of America website and for the term "nuclear" on the Press TV website. The initial search was conducted on February 3, 2019, and data was collected for news reports published between Monday, May 7, 2018, and Monday, May 14, 2018. Relevant news reports were downloaded via web browser and saved to the author's computer to ensure continued access to the material. Web links to each report were revisited later to ensure continued availability on each news organization's respective website.

The author examined headline tone based on evaluative criteria used in previous similar research (Cain and Drumheller, 2019; Cain and Drumheller, 2014). Examples of positive tone include headlines expressing a favorable position toward the United States' withdrawal, referencing support for maintaining relationships with Iran, or using words such as "welcomes" or "cooperating." A headline exhibiting negative tone would include words such as "misguided" or "foolish" or highlight potential negative consequences associated with the decision. A statement of fact would represent neutral tone.

\section{Analysis}

\section{Press TV}

There was an eight-and-a-half-hour time difference between Washington, D.C., and Tehran on May 8, 2018, when President Trump announced the U.S. withdrawal from the JCPOA, so it was Tuesday evening in Iran when Press TV began reporting on the decision. In the first several hours after the announcement, Press TV featured nine related news reports on its website. Five headlines, approximately 56 percent, were classified as negative in tone.

\footnotetext{
"Nuclear non-proliferation regime is at stake, Macron says" (2018)

"Israel puts army on alert in Golan Heights as Trump quits from JCPOA" (2018)

“Trump's decision to quit Iran nuclear deal is 'misguided,' Obama says” (2018)

"Trump trying to satisfy Israel by reneging on Iran deal: Scholar" (2018)
} 
“UK foreign secretary regrets Trump's decision on Iran” (2018)

The headline focusing on French President Emmanuel Macron's concerns about the U.S. withdrawal from the JCPOA exhibits negative tone because it implies an unwelcome disruption in the global nuclear non-proliferation status quo. Reference to Israel placing its army on alert suggests fear of negative regional political consequences as a result of President Trump's announcement. Finally, three of these headlines include words with negative connotations: "misguided," "reneging," and "regrets." Only one headline from the May 8 group exhibited positive tone.

"Riyadh 'supports and welcomes' Trump's JCPOA move: Saudi Foreign Ministry" (2018)

On the surface, the language presents Saudi Arabia's response to the news in a positive light. In a strict sense, this classifies the headline into the positive tone group. However, this headline also includes an underlying tone that could be classified as negative. Iran and Saudi Arabia are "bitter rivals" that compete against each other for regional dominance (Marcus, 2019). Explicitly acknowledging that a geopolitical competitor is praising the re-imposition of sanctions against Iran provides an implicitly-negative cue to the reader. Finally, three headlines, approximately 33 percent, were classified as neutral in tone.

“Trump announces 'withdrawal' from Iran nuclear deal” (2018)

"President Rouhani says Iran will stay in JCPOA" (2018)

"Reactions to Trump's JCPOA withdrawal from inside the US" (2018)

These three headlines made basic statements of fact and did not include overt negative or positive connotations.

Press TV published 26 headlines related to the JCPOA on Wednesday, May 9, 2018. Eighteen of them, approximately 69 percent, were classified as exhibiting negative tone. They can be grouped into two general categories: negative economic consequences and negative political consequences. Fourteen of these focused on the political consequences of President Trump's decision.

"Major EU-US divisions over JCPOA" (2018)

"France's Macron says Trump made a mistake by leaving JCPOA" (2018)

"Leader: Trump's speech against Iran 'silly and superficial"” (2018)

“Abandoning Iran nuclear deal Trump's 'most foolish decision yet': Rice"

(2018)

"Iran vows to boost defense program despite US threats" (2018) 
"US flag up in flames inside Iranian parliament after Trump nixes nuclear deal" (2018)

"Iranian protesters burn American flags outside former US embassy in Tehran" (2018)

"US following Israeli diktats over Iran nuclear deal: Commentator" (2018)

"Iran officials slam US withdrawal from JCPOA" (Naderi, 2018)

"Italy fears consequences of US withdrawal from JCPOA" (Civili, 2018)

"Trump's decision could end the very empire he's trying to protect: Scholar" (2018)

“UN Sec. Gen. expresses ‘concern’ about US withdrawal from Iran deal” (2018)

"With Iran deal withdrawal, US officially becomes 'a rogue nation”" (2018)

"Iran press, people react after Trump pulls US out of nuclear deal" (2018)

Some of these headlines indicate negative tone by featuring the words "mistake," "silly," "foolish," "threats," "slam," and "rogue." Others, such as those describing incidents where the U.S. flag was burned in protest, indicate negative intent. Collectively, these headlines focus on the concerns, fears, and suspicions expressed in the first two days after President Trump's announcement. It must also be noted that variations of the infinitive phrase "to pull out" or the word "quit" regarding the decision to leave the JCPOA have been classified as negative, whereas use of the word "withdrawal" is considered neutral. To "pull out" of something has an attached negative connotation that variations of the term "withdraw" do not. The remaining four headlines featuring negative tone included language signaling grim economic repercussions as a result of the U.S. withdrawal.

"Defiance expected to Trump's Iran oil sales curbs" (2018)

"Oil hits new highs after Trump quits Iran deal” (2018)

"Boeing, Airbus licenses to sell jets to Iran to be revoked: US Treasury" (2018)

“Iran sanctions to cost Boeing, Airbus \$39bn” (2018)

The first two headlines listed above suggest the decision will negatively impact the global oil market. The last two headlines specifically reference negative consequences for Boeing, Airbus, and Iran. In September 2016, the United States removed final regulatory hurdles and allowed the two aircraft manufacturers to sell planes directly to Iran (Erdbrink and Clark, 2016). After the announced withdrawal from the JCPOA, however, the U.S. Treasury Department announced the U.S. 
"would no longer allow the export of commercial passenger aircraft, parts and services to Iran after a 90-day period" (Lawder, 2018).

Seven headlines, or 27 percent, were positive in tone. All of them focused on other international actors who expressed support for Iran, for the JCPOA, or for companies that desired to continue working with Iran.

"EU, Russia, China rally behind Iran after Trump's move" (2018)

"Boris Jonson: Britain has 'no intention of walking away' from the Iran nuclear deal" (2018)

"Britain vows to stand by Iran deal despite US withdrawal" (Taylor, 2018)

“EU pledges commitment to Iran nuclear deal, regrets Trump decision” (2018)

“France, EU back Iran deal despite Trump's pullout” (Mazaheri, 2018a)

“Germany vows to protect EU firms against Iran bans" (2018)

“Iran implementing commitments under JCPOA: UN watchdog” (2018)

Only one Press TV headline from May 9 was classified as neutral in tone, and it concerned a factual statement about a decision made in Iran's Parliament.

“Iran MPs table motion on response to Trump decision" (2018)

Though Press TV published fewer headlines about the JCPOA on Thursday, May 10, 2018, tone in 10 of the 13 headlines was negative. That is approximately 77 percent.

"US turning its back on allies by quitting Iran deal: EU's Juncker" (2018)

"US pullout from Iran nuclear deal; part of a larger strategy: Analyst" (2018)

“US withdrawal from Iran deal violates UN resolution: Russian FM” (2018)

"Lawbreaking, breach of promises habitual for US govt.: Iran" (2018)

"The US road to hell is littered with broken treaties: American writer" (2018)

“Trump made 'serious mistake’ by leaving Iran nuclear deal: Carter” (2018)

“Trump deserves impeachment for Iran deal withdrawal: Waters" (2018)

“Rouhani urges efforts against US 'unilateralism' in phone call with Erdogan” (2018)

"OPEC in no hurry to offset possible loss from Iran's oil flow after US sanctions: Sources" (2018) 
Vol. 8, No. $1 \quad$ Cain: "Silly and Superficial": Headline Tone in Press TV and Voice...

"Saudi Arabia to build nuclear bomb if Iran does so: FM" (2018)

Individually, several of these headlines accuse the United States of abandoning its allies, breaking its promises, and violating its international agreements. Concerns about how the United States' decision would affect global oil markets are referenced again, and the specter of a nuclear arms race in the Middle East is openly considered. Collectively, these headlines provide readers with a clear indication that President Trump's decision was a poor one.

Only one headline exhibited positive tone, and it indicated Russia's willingness to continue working with Iran on the Joint Comprehensive Plan of Action without U.S. involvement.

"Iran, Russia to continue cooperating on JCPOA even after US exit from deal: Moscow" (2018)

Finally, two of the day's headlines, approximately 15 percent, exhibited neutral tone.

"Debate: Future of Iran nuclear deal" (2018)

"Iranian President Rouhani, French President Macron talk on future of JCPOA" (Mazaheri, 2018b)

\section{Voice of America}

Voice of America published nine headlines on May 8, 2018, the day President Trump announced the United States would leave the JCPOA and reinstate sanctions against Iran. Six of them, approximately 67\%, were classified as exhibiting negative tone.

"VOA Asia - Trump pulls U.S. out of Iran nuclear deal as North Korea summit looms" (2018)

“Iran Faces Banking Turmoil After US Nuclear Deal Exit” (2018)

"New US Ambassador to Berlin Warns German Businesses to Leave Iran” (2018)

"Mnuchin: US Revoking Boeing, Airbus Licenses to Sell Jets to Iran” (2018)

“AP FACT CHECK: Trump vs. Truth on the Iran Nuclear Deal” (2018)

“Trump’s Iran Deal Decision Revives Bitter Hill Debate” (Gypson, 2018)

Words and phrases such as "pulls U.S. out," "turmoil," "revoking," "Trump vs. Truth," and "bitter" have negative connotations and exhibit darker tone. Voice of America published no headlines categorized as featuring positive tone on May 8 , but the remaining three published that day, approximately 33 percent, used straightforward descriptive terms to indicate each report's content, striking a neutral tone. 
“VOA60 World PM - Trump Withdraws US From Iran Nuclear Deal” (2018)

“Mideast Facing Week of Milestone Events" (2018)

“Families Wonder How Iran Decision Will Impact US Detainees" (2018)

Voice of America published 14 headlines related to the JCPOA on May 9, 2018, about half as many Press TV published that same day. Nine headlines, or 64 percent, were categorized as having negative tone.

"Pulling Out of the Iran Nuclear Agreement" (2018)

“Iran Deal Exit Complicates But Shouldn’t Derail Korea Talks” (Padden, 2018)

"Europe Pledges to Defend Interests in Wake of US Pull-out From Iran Nuclear Deal" (Ridgwell, 2018a)

"Europe Vows to Defend Its Interests in Iran" (Ridgwell, 2018b)

"Trump: 'Very Severe Consequences' if Iran Starts Nuclear Weapons Program" (2018)

"OPEC Source: Saudi Arabia Will Not Act Alone to Fill Any Iran Oil Shortfall" (2018)

"US to Press Europe to Reduce Iran Investments" (Aryan and Lipin, 2018)

"US Withdraws from Iran Nuclear Deal; Allies Say It's Not Dead Yet" (Herman, 2018)

"Iran Deal Signatories Still Committed After US Exit” (Bredemeier, 2018a)

Several of these headlines portend potential adverse international consequences, particularly for the relationship between the United States and Europe. Nuclear negotiations with North Korea and global oil supplies are also specifically referenced as areas of concern. Regarding positive-toned headlines, 29 percent of Voice of America's Iran-related headlines published on May 9 were included in that category.

“Energy Stocks Jump on Wall Street After US Quits Iran Deal” (2018)

"Son Sees Hope for Missing American in US-Iran Deal Exit" (Lipin and Yazdian, 2018)

“Gulf Allies Applaud Trump Decision to Scrap Iran Nuclear Deal” (Yeranian, 2018)

“Israel Welcomes Trump’s ‘Bold’ Decision to Leave Iran Deal” (Berger, 2018) 
Though positive on their surface, two of these headlines exhibit underlying tone that could be classified as negative. Statements regarding praise from Gulf allies and Israel for the U.S. withdrawal from the JCPOA acknowledge regional tensions. Israel and Iran are regional rivals that recently took opposing sides in Syria's proxy war (Marcus, 2018). The subtexts of these two headlines take a dim view of Iran and its regional intentions. Finally, only one published headline exhibited neutral tone.

“Trump Withdraws US from Iran Nuclear Deal” (Gallo, 2018)

Voice of America published four news headlines related to the JCPOA announcement on Thursday, May 10, 2018. Three of them, or 75 percent, featured negative tone.

"US Looks for Allied Support to Pressure Iran" (Bredemeier, 2018b)
"Turkey, US Could Head for Collision Over Iran Nuclear Deal" (Jones, 2018)
"Iranian Currency Slumps on Black Market After US Quits Iran Deal" (Lipin and
Bahraminejad, 2018)

The first two suggest potentially negative political consequences, while the third suggests a possible economic consequence concerning Iran's currency. The only other headline VOA published regarding the JCPOA exhibited positive tone.

“Trump Says Iran Will Agree to Negotiate on Nuclear Deal” (Hoke, 2018)

This headline implies Iran will accept President Trump's decision and will return to the negotiating table for a new agreement.

\section{Discussion}

On May 8, 2018, both Press TV and VOA published nine reports concerning President Trump's announcement that the United States would leave the Joint Comprehensive Plan of Action with Iran. The numbers were the same despite Voice of America having more than eight additional hours of publication opportunities on that date because of the time difference between the United States and Iran. On May 9, Press TV published almost twice as many reports as did VOA, 26 to 14, respectively. That imbalance was evident again on May 10, when Press TV published 13 reports to VOA's four, more than three times as many. This suggests Press TV, which is based in the country most negatively affected by the U.S. withdrawal, perceived a greater obligation to provide continuing coverage of this event to its audience than did Voice of America. The number of news reports published in the days beyond the scope of this research provides anecdotal support for this idea. Between May 11 and May 13, Press TV published an additional 24 
news reports concerning the U.S. withdrawal from the JCPOA. During the same time frame, Voice of America published eight.

Regarding headline tone, it should be noted that some headlines that seem similar in content were classified as either negative or positive depending upon which news organization published them. For example, headlines indicating European support for the JCPOA or Iran were classified as having positive tone if published by Press TV because they implied support for the broadcaster's home country. Similar headlines published by Voice of America, however, were classified as having negative tone because they implied an oppositional stance to the new U.S. position. The concept of tone being analyzed not only by the specific words of the headline, but also by the news organization's location or the audience's cultural and political perspectives, deserves further consideration.

\section{Conclusion}

This descriptive content analysis is inherently inductive and stops short of making theoretical suggestions. However, by analyzing three days of headlines published by these international broadcasters, the results provide promise for constructing hypotheses that could be explored in future studies. One potential hypothesis could focus on the possibility that the majority of headlines published during the first few days of a breaking international news story may exhibit negative tone simply because the status quo has changed. A second potential hypothesis could suggest that a larger percentage of headlines may exhibit negative tone when published by news organizations located in a country that is significantly impacted by whatever international change has occurred. A third potential hypothesis could concern the type of tone present in headlines published by news organizations that represent the point of view held by their country's political authority, whether the event in question could be interpreted as negatively or positively affecting that country.

This analysis has limitations. Only two international broadcasters, Press TV and Voice of America, were included in this research. Examining headlines published by other international broadcasters may provide results that change the percentages of headlines exhibiting negative, positive, or neutral tone. Examining headlines published by news organizations located in Iran's regional political rivals, such as Israel and Saudi Arabia, would likely yield different results. This research does not address whether the full published reports on each news organization's website adhere to the tone suggested by their respective headlines. Finally, the content analyzed in this research was published in English, meaning the information was intended for a global English-speaking audience. Examination of content produced for non-English-speaking audiences may yield different results.

Studying headlines published by international news organizations opens a window into how the global media system operates. Such exploration provides insight into the ways these organizations choose to inform their global audiences, and it offers clues about how information providers potentially influence audience 
reactions through headline choices. This line of inquiry also creates an opportunity to examine how published headlines reflect each organization's stated mission. Finally, studying news headlines can offer hints as to the tone an organization's future coverage of a particular international issue might take. Recognizing these aspects of headline construction and publication could shape global media consumers' understanding of how news media organizations use headlines to depict important international events.

\section{References}

Abandoning Iran nuclear deal Trump's 'most foolish decision yet': Rice (2018, May 9). Press TV. Retrieved from: https://www.presstv.com/Detail/2018/ 05/09/561133/Do nald-Trumps-most-foolish-decision-yet. [Accessed 8 July 2020]

About PressTV (2017, August 13). PressTV. Retrieved from: https:// www.presstv.com/ Detail/2014/12/31/390988/About-PressTV. [Accessed 8 July 2020]

Andrew, B. (2007). Media-generated shortcuts: do newspaper headlines present another roadblock for low-information rationality? The Harvard International Journal of Press/Politics, 12(2), 24-43.

AP fact check: Trump vs. truth on the Iran nuclear deal (2018, May 8). Associated Press. Retrieved from: https://www.voanews.com/usa/us-politics/ap-fact-check-trump-vstruth-iran-nuclear-deal. [Accessed 9 July 2020]

Aryan, G., Lipin, M. (2018, May 9). US to press Europe to reduce Iran investments. Voice of America. Retrieved from: https://www.voa news.com/middle-east/voa-newsiran/us-press-europe-reduce-iran-investments. [Accessed 9 May 2018]

Behravesh, M. (2013). Press TV: Iran's revisionist voice in perspective. Asian Politics \& Policy, 5(4), 683-686.

Berger, R. (2018, May 9). Israel welcomes Trump's 'bold' decision to leave Iran deal. Voice of America. Retrieved from: https://www.voanews.com/mid dle-east/israel-welcome s-trumps-bold-decision-leave-iran-deal. [Accessed 9 July 2020]

Boeing, Airbus licenses to sell jets to Iran to be revoked: US Treasury (2018, May 9). Press TV. Retrieved from: https://www.presstv.com/Detail/2018/05/ 09/561093/IranJCPOA-Boeing-Airbus. [Accessed 8 July 2020]

Boris Jonson: Britain has 'no intention of walking away' from the Iran nuclear deal (2018, May 9). Press TV. Retrieved from: https://www.presstv.com/ Detail/2018/05/09/56 1149/UK-has-no-intention-of-walking-away-from-nuclear-deal. [Accessed 8 July 2020]

Bredemeier, K. (2018a, May 9). Iran deal signatories still committed after US exit. Voice of America. Retrieved from: https://www.voanews.com/mid dle-east/iran-deal-signato ries-still-committed-after-us-exit. [Accessed 9 July 2020]

Bredemeier, K. (2018b, May 10). US Looks for allied support to pressure Iran. Voice of America. Retrieved from: https://www.voanews.com/usa/us-politics/us-looks-alliedsupport-pressure-iran. [Accessed 17 September 2020]

Cain, B., Drumheller, K. (2014). Broken promises: agenda setting and tone in news stories about North Korea's nuclear program. GSTF Journal on Media \& Communications, 2(1), 34-39.

Cain, B., Drumheller, K. (2019). A rogue nation: news headline tone in international coverage of North Korea's September 2017 nuclear test. Athens Journal of Mass Media and Communications, 5(1), 1-16. 
Civili, M. (2018, May 9). Italy fears consequences of US withdrawal from JCPOA. Press TV. Retrieved from: https://www.presstv.com/Detail/2018/5/9/561192/www.press tv.tv. [Accessed 8 July 2020]

Debate: Future of Iran nuclear deal (2018, May 10). Press TV. Retrieved from: http:// www.presstv.com/Detail/2018/05/10/561186/Debate-US-with drawal-Iran-nucleardeal. [Accessed 17 September 2020]

Defiance expected to Trump's Iran oil sales curbs (2018, May 9). Press TV. Retrieved from: https://www.presstv.com/Detail/2018/05/09/561178/Defiance-expected-to-Tru mps-Iran-oil-sales-curbs. [Accessed 8 July 2020]

Dor, D. (2003). On newspaper headlines as relevance optimizers. Journal of Pragmatics 35(5), 695-721.

Energy stocks jump on Wall Street after US quits Iran deal (2018, May 9). Reuters. Retrieved from: https://www.voanews.com/archive/energy-stocks-jump-wall-streetafter-us-quits-iran-deal. [Accessed 9 May 2018]

Entman, R. (2007). Framing bias: Media in the distribution of power. Journal of Communication, 57(1), 163-173.

Erdbrink, T., Clark, N. (2016, Sept. 21). U.S. allows Boeing and Airbus to sell planes to Iran. The New York Times. Retrieved from: https://www.nytimes.com/2016/09 /22/world/middleeast/iran-airbus-boeing-aircraft.html. [Accessed 16 July 2020]

EU pledges commitment to Iran nuclear deal, regrets Trump decision (2018, May 9). Press TV. Retrieved from: https://www.presstv.com/Detail/2018/05/ 09/561167/EU-Irandeal-Mogherini-Trump-US-Macron. [Accessed 8 July 2020]

EU, Russia, China rally behind Iran after Trump's move (2018, May 9). Press TV. Retrieved from: https://www.presstv.com/Detail/2018/05/09/5611 13/France-Iran-JC POA. [Accessed 8 July 2020]

Families wonder how Iran decision will impact US detainees (2018, May 8). Associated Press. Retrieved from: https://www.voanews.com/usa/fa milies-wonder-how-irandecision-will-impact-us-detainees. [Accessed 9 July 2020]

France's Macron says Trump made a mistake by leaving JCPOA (2018, May 9). Press TV. Retrieved from: https://www.presstv.com/detail/2018/05/ 09/561189/france-irantrump-jcpoa-macron. [Accessed 8 July 2020]

Gallo, W. (2018, May 9). Trump withdraws us from Iran nuclear deal. Voice of America. Retrieved from: https://www.voanews.com/episode/trump-withdraws-us-iran-nucl ear-deal-3778531. [Accessed 9 July 2020]

Germany vows to protect EU firms against Iran bans. (2018, May 9). Press TV. Retrieved from: https://www.presstv.com/Detail/2018/05/09/5611 65/Germany-vows-toprotect-EU-firms-against-Iran-bans- [Accessed 8 July 2020]

Gordon, M., Sanger, D. (2015, July 14). Deal reached on Iran nuclear program; limits on fuel would lessen with time. The New York Times. Retrieved from: https://www. nytimes.com/2015/07/15/world/middleeast/iran-nuclear-deal-is-reached-after-longnegotiations.html?searchResultPosition=13. [Accessed 10 May 2020]

Gypson, K. (2018, May 8). Trump's Iran deal decision revives bitter hill debate. Voice of America. Retrieved from: https://www.voanews.com/usa/trumps-iran-deal-decisionrevives-bitter-hill-debate. [Accessed 9 July 2020]

Herman, S. (2018, May 9). US withdraws from Iran nuclear deal; Allies say it's not dead yet. Voice of America. Retrieved from: https://www.voanews.com/usa/us-withdraws -iran-nuclear-deal-allies-say-its-not-dead-yet. [Accessed 9 July 2020]

Hoke, Z. (2018, May 10). Trump Says Iran Will Agree to Negotiate on Nuclear Deal. Voice of America. Retrieved from: https://www.voanews.com/episode/trump-saysiran-will-agree-negotiate-nuclear-deal-3778756. [Accessed 17 September 2020] 
Vol. 8, No. $1 \quad$ Cain: "Silly and Superficial": Headline Tone in Press TV and Voice...

Ifantidou, E. (2009). Newspaper headlines and relevance: Ad hoc concepts in ad hoc contexts. Journal of Pragmatics, 41(4), 699-720.

Iran faces banking turmoil after US nuclear deal exit. (2018, May 8). Reuters. Retrieved from: https://www.voanews.com/middle-east/iran-faces-banking-turmoil-after-us-nuc lear-deal-exit. [Accessed 9 July 2020]

Iran implementing commitments under JCPOA: UN watchdog (2018, May 9). Press TV. Retrieved from: https://www.presstv.com/Detail/2018/05/09/561145/Iran-IAEA-Am ano-JCPOA-Trump. [Accessed 8 July 2020]

Iran MPs table motion on response to Trump decision (2018, May 9). Press TV. Retrieved from: https://www.presstv.com/Detail/2018/05/09/56110 2/Iran-JCPOA-Ali-Larijani. [Accessed 8 July 2020]

Iran press, people react after Trump pulls US out of nuclear deal (2018, May 9). Press TV. Retrieved from: https://www.presstv.com/Detail/2018/05/09/5 61106/Iran-US-Trum p-nuclear-press-people-reaction. [Accessed 8 July 2020]

Iran, Russia to continue cooperating on JCPOA even after US exit from deal: Moscow (2018, May 10). Press TV. Retrieved from: https://www.presstv.com/Detail/2018/ 05/10/561276/Russia-Iran-JCPOA-US-cooperation-EU-UN

Iran sanctions to cost Boeing, Airbus \$39bn (2018, May 9). Press TV. Retrieved from: https://www.presstv.com/Detail/2018/05/09/561148/Iran-sanctions-to-cost-BoeingAirbus-39bn- [Accessed 8 July 2020]

Iran vows to boost defense program despite US threats (2018, May 9). Press TV. Retrieved from: https://www.presstv.com/Detail/2018/05/09/56116 0/Iran-missileprogram-US-withdrawal-JCPOA. [Accessed 8 July 2020]

Iranian protesters burn American flags outside former US embassy in Tehran (2018, May 9). Press TV. Retrieved from: https://www.presstv.com/Detail/ 2018/05/09/561161/I ran-Protest-US-Deal. [Accessed 8 July 2020]

Israel puts army on alert in Golan Heights as Trump quits from JCPOA (2018, May 8). Press TV. Retrieved from: https://www.presstv.com/Detail/2018/05/08/561075/isra el-golan-heights-missiles. [Accessed 8 July 2020]

Jones, D. (2018, May 10). Turkey, US Could Head for Collision Over Iran Nuclear Deal. Voice of America. Retrieved from: https://www.voanews. com/middle-east/turkeyus-could-head-collision-over-iran-nuclear-deal. [Accessed 17 September 2020]

Key moments in the unraveling of Iran's nuclear deal (2020, January 14). The Associated Press. Retrieved from: https://apnews.com/fb526a83 12649c155968ad76437318f0. [Accessed 28 July 2020]

Landler, M. (2018, May 8). Trump abandons Iran nuclear deal he long scorned. The New York Times. Retrieved from: https://www.nytimes.com/2018/05/08/world/middlee ast/trump-iran-nuclear-deal.html?searchResultPosition=20. [Accessed 10 May 2020]

Laub, Z., Robinson, K. (2020, January 7). What is the status of the Iran nuclear agreement? Council on Foreign Relations. Retrieved from: https://www.cfr.org/backgrounder/ what-status-iran-nuclear-agreement. [Accessed 28 July 2020]

Lawbreaking, breach of promises habitual for US govt.: Iran (2018, May 10). Press TV. Retrieved from: https://www.presstv.com/Detail/2018/05/10/561286/Iran-US-JCPOA. [Accessed 17 September 2020]

Lawder, D. (2018, May 8). U.S. Treasury's Mnuchin: Revoking Boeing, Airbus licenses to sell jets to Iran. Reuters. Retrieved from: https://www.re uters.com/article/us-irannuclear-boeing/u-s-treasurys-mnuchin-revoking-boeing-airbus-licenses-to-sell-jetsto-iran-idUSKBN1I92Q6. [Accessed 16 July 2020]

Leader: Trump's speech against Iran 'silly and superficial' (2018, May 9). Press TV. Retrieved from: https://www.presstv.com/Detail/2018/05/09/561123/Iran-Ali-Shamk hani-Pakistan. [Accessed 8 July 2020] 
Leckner, S. (2012). Presentation factors affecting reading behaviour in readers of newspaper media: An eye-tracking perspective. Visual Communication, 11(2), 163184.

Lipin, M., Bahraminejad, S. (2018, May 10). Iranian Currency Slumps on Black Market After US Quits Iran Deal. Voice of America. Retrieved from: https://www.voanews. com/world-news/middle-east-dont-use/iranian-curren cy-slumps-black-market-afterus-quits-iran-deal. [Accessed 17 September 2020]

Lipin, M., Yazdian, P. (2018, May 9). Son sees hope for missing American in US-Iran deal exit. Voice of America. Retrieved from: https://www.voane ws.com/middleeast/voa-news-iran/son-sees-hope-missing-american-us-iran-deal-exit. [Accessed 9 July 2020]

Major EU-US divisions over JCPOA (2018, May 9). Press TV. Retrieved from: http:// www.presstv.com/Detail/2018/05/09/561170/EUUS-divisions-JCPOA. [Accessed 8 July 2020]

Marcus, J. (2018, May 10). Your questions answered on Iran and Israel relations. BBC. Retrieved from: https://www.bbc.com/news/world-middle-east-44069932. [Accessed 17 July 2020]

Marcus, J. (2019, Sept. 16). Why Saudi Arabia and Iran are bitter rivals. BBC. Retrieved from: https://www.bbc.com/news/world-middle-east-420 08809. [Accessed 10 July 2020]

Masterson, J. (2020, July). Timeline of nuclear diplomacy with Iran. Arms Control Association. Retrieved from: https://www.armscontrol.org/factshe ets/Timeline-ofNuclear-Diplomacy-With-Iran. [Accessed 28 July 2020]

Mazaheri, R. (2018a, May 9). France, EU back Iran deal despite Trump's pullout. Press TV. Retrieved from: http://www.presstv.com/Detail/2018/05/ 09/561082/France-EUback-Iran-deal-despite-Trumps-pullout- [Accessed 8 July 2020]

Mazaheri, R. (2018b, May 10). Iranian President Rouhani, French President Macron talk on future of JCPOA. Press TV. Retrieved from: http://www. presstv.com/Detail/ 2018/05/10/561291/Rouhani--Macron-talk-on-future-of-JCP OA

Mideast facing week of milestone events (2018, May 8). Associated Press. Retrieved from: https://www.voanews.com/middle-east/mideast-facing-week-milestone-events. [Accessed 9 July 2020]

Mission and values (n.d.). Voice of America. Retrieved from: https://www.insidevoa.com /p/5831.html. [Accessed 8 July 2020]

Mnuchin: US revoking Boeing, Airbus licenses to sell jets to Iran. (2018, May 8). Reuters. Retrieved from: https://www.voanews.com/middle-east/voa-news-iran/mnuchin-usrevoking-boeing-airbus-licenses-sell-jets-iran. [Accessed 9 July 2020]

Naderi, G. (2018, May 9). Iran officials slam US withdrawal from JCPOA. Press TV. Retrieved from: https://www.presstv.com/Detail/2018/05/09/5611 69/Iran-US-with drawal-JCPOA. [Accessed 8 July 2020]

New US Ambassador to Berlin warns German businesses to leave Iran (2018, May 8). Voice of America. Retrieved from: https://www.voanews.com/world-news/middleeast-dont-use/new-us-ambassador-berlin-warns-german-businesses-leave-iran. [Accessed 8 July 2020]

Nisar, H., Bleich, E. (2020). Group status, geographic location, and the tone of media coverage: Jews and Muslims in New York Times and Guardian Headlines, 19852014. Comparative Migration Studies, 8(3), 1-18.

Nuclear non-proliferation regime is at stake, Macron says (2018, May 8). Press TV. Retrieved from: https://www.presstv.com/Detail/2018/05/08/561072/iran-us-eu-jcp oa-trump. [Accessed 8 July 2020] 
Oil hits new highs after Trump quits Iran deal (2018, May 9). Press TV. Retrieved from: https://www.presstv.com/Detail/2018/05/09/561155/Oil-hits-new-highs-after-Trumpquits-Iran-deal. [Accessed 8 July 2020]

OPEC in no hurry to offset possible loss from Iran's oil flow after US sanctions: Sources (2018, May 10). Press TV. Retrieved from: https://www.presstv.com/Detail/2018/05 /10/561243/OPEC-Iran-oil-supply-sanctions

OPEC source: Saudi Arabia will not act alone to fill any Iran oil shortfall (2018, May 9). Reuters. Retrieved from: https://www.voanews.com/middle-east/opec-source-saudiarabia-will-not-act-alone-fill-any-iran-oil-shortfall. [Accessed 9 July 2020]

Padden, B. (2018, May 9). Iran deal exit complicates but shouldn't derail Korea talks. Voice of America. Retrieved from: https://www.voanews.com/east-asia-pacific/irandeal-exit-complicates-shouldnt-derail-korea-talks. [Accessed 9 July 2020]

President Rouhani says Iran will stay in JCPOA (2018, May 8). Press TV. Retrieved from: https://www.presstv.com/Detail/2018/05/08/561071/iran-us-rouhani-trump-jcpoa. [Accessed 8 July 2020]

Pulling out of the Iran nuclear agreement (2018, May 9). Voice of America. Retrieved from: https://www.voanews.com/episode/pulling-out-iran-nuclear-agreement-1861 586. [Accessed 9 July 2020]

Reactions to Trump's JCPOA withdrawal from inside the US (2018, May 8). Press TV. Retrieved from: https://www.presstv.com/Detail/2018/05/08/5 61073/US-iran-nuc lear-Democrats. [Accessed 8 July 2020]

Ridgwell, H. (2018a, May 9). Europe pledges to defend interests in wake of US pull-out from Iran nuclear deal. Voice of America. Retrieved from: https://www.voanews.Co m/episode/europe-pledges-defend-interests-wake-us-pull-out-iran-nuclear-deal-3778 471. [Accessed 9 July 2020]

Ridgwell, H. (2018b, May 9). Europe vows to defend its interests in Iran. Voice of America. Retrieved from: https://www.voanews.com/episode/europe-vows-defendits-interests-iran-3778656. [Accessed 9 July 2020]

Riyadh 'supports and welcomes' Trump's JCPOA move: Saudi Foreign Ministry (2018, May 8). Press TV. Retrieved from: https://www.presstv.com/Detail/2018/05/08/56 1079/saudi-arabia-us-trump-jcpoa. [Accessed 8 July 2020]

Rouhani urges efforts against US 'unilateralism' in phone call with Erdogan (2018, May 10). Press TV. Retrieved from: http://www.presstv.com/ Detail/2018/05/10/561267/ Rouhani-Erdogan-Iran-Deal-US. [Accessed 17 September 2020]

Rowberry, A. (2013, December 18). Sixty years of “Atoms for Peace” and Iran's nuclear program. Brookings. Retrieved from: https://www.brooking s.edu/blog/up-front/2013 /12/18/sixty-years-of-atoms-for-peace-and-irans-nuclear-program/. [Accessed 28 July 2020]

Saudi Arabia to build nuclear bomb if Iran does so: FM (2018, May 10). Press TV. Retrieved Sept. 17, 2020 from https://www.presstv.com/Detail/2018/05/10/561210/ Iran-Saudi-Arabia-nuclear-bomb. [Accessed 17 September 2020]

Sheafer, T. (2007). How to evaluate it: The role of story-evaluative tone in agenda setting and priming. Journal of Communication, 57(1), 21-39.

Steinhauer, J. (2015, Sept. 10). Democrats hand victory to Obama on Iran nuclear deal. The New York Times. Retrieved from: https://www.nytimes.com/2015/09/11/us/poli tics/iran-nuclear-deal-senate.html?searchResultPosition=14. [Accessed 10 May 2020]

Taylor, A. (2018, May 9). Britain vows to stand by Iran deal despite US withdrawal. Press TV. Retrieved from: https://www.presstv.com/Detail/2018/05/09/561191/Britain-Vo ws-To-Stand-By-Iran-Deal-Despite-US-Withdrawal. [Accessed 8 July 2020] 
The Joint Comprehensive Plan of Action (JCPOA) at a glance (2018, May). Arms Control Association. Retrieved from: https://www.armscontrol.org/ factsheets/JCPOA-at-aglance. [Accessed 28 July 2020]

The US road to hell is littered with broken treaties: American writer (2018, May 10). Press TV. Retrieved from: https://www.presstv.com/Detail/2018/ 05/10/561290/The-USroad-to-hell-is-littered-with-broken-treaties. [Accessed 17 September 2020]

Trump announces 'withdrawal' from Iran nuclear deal (2018, May 8). Press TV. Retrieved from: https://www.presstv.com/Detail/2018/05/08/561068/Iran-nuclear-deal-Trumpus-jcpoa. [Accessed 8 July 2020]

Trump deserves impeachment for Iran deal withdrawal: Waters (2018, May 10). Press TV. Retrieved from: https://www.yjc.ir/en/news/22734/trump-de serves-impeachmentfor-iran-deal-withdrawal-waters. [Accessed 17 September 2020]

Trump made 'serious mistake' by leaving Iran nuclear deal: Carter (2018, May 10). Press TV. Retrieved from: https://www.presstv.com/Detail/2018/ 05/10/561230/Jimmycarter-US-President-Iran-nuclear-deal. [Accessed 17 September 2020]

Trump trying to satisfy Israel by reneging on Iran deal: Scholar (2018, May 8). Press TV. Retrieved from: https://www.presstv.com/Detail/2018/05/08/ 561066/Trump-tryingto-satisfy-Israel-by-reneging-on-Iran-nuclear-deal [Accessed 8 July 2020]

Trump: 'Very severe consequences' if Iran starts nuclear weapons program (2018, May 9). Voice of America. Retrieved from: https://www.voanews.com/middle-east/trump -very-severe-consequences-if-iran-starts-nuclear-weapons-program. [Accessed 9 July 2020]

Trump's decision could end the very Empire he's trying to protect: Scholar (2018, May 9). Press TV. Retrieved from: http://french.presstv.com/Detail/2018/05/09/561180/Tru mps-decision-could-end-the-very-Empire-hes-trying-to-pr otect. [Accessed 8 July 2020]

Trump's decision to quit Iran nuclear deal is 'misguided,' Obama says (2018, May 8). Press TV. Retrieved from: https://www.presstv.com/Detail/2018/05/08/561076/Tru mp-is-misguided-Obama-says. [Accessed 8 July 2020]

UK foreign secretary regrets Trump's decision on Iran (2018, May 8). Press TV. Retrieved from: http://french.presstv.com/Detail/2018/05/08/561074/UK-Theresa-May-JCPOA -Donald-Trump. [Accessed 8 July 2020]

UN Sec. Gen. expresses 'concern' about US withdrawal from Iran deal (2018, May 9). Press TV. Retrieved from: http://french.presstv.com/Detail/2018/05/09/561081/USA UN-Sec-Gen-expresses-concern-about-US-exit-from-Iran-deal. [Accessed 8 July 2020]

US flag up in flames inside Iranian parliament after Trump nixes nuclear deal (2018, May 9). Press TV. Retrieved from: https://www.presstv.com/Detail/2018/05/09/561142/ Iran-nuclear-deal-US-Donald-Trump. [Accessed 8 July 2020]

US following Israeli diktats over Iran nuclear deal: commentator (2018, May 9). Press TV. Retrieved from: https://www.presstv.com/Detail/2018/ 05/09/561104/Iran-TrumpJCPOA. [Accessed 8 July 2020]

US pullout from Iran nuclear deal; part of a larger strategy: analyst (2018, May 10). Press TV. Retrieved from: https://www.presstv.com/Detail/2018/ 05/10/561209/US-Irannuclear-agreement--JCPOA-Trump-sanctions. [Accessed 17 September 2020]

US turning its back on allies by quitting Iran deal: EU's Juncker (2018, May 10). Press TV. Retrieved from: https://www.presstv.com/Detail/2018/05/10/561205/EU-Junck r -US-Iran-deal-JCPOA-German-Chancellor-Angela-Merkel. [[Accessed 17 September 2020] 
Vol. 8, No. $1 \quad$ Cain: "Silly and Superficial": Headline Tone in Press TV and Voice...

US withdrawal from Iran deal violates UN resolution: Russian FM (2018, May 10). Press TV. Retrieved from: https://www.presstv.com/detail/2018/05/10/561245/russia-lavro v-iran-deal-us. [Accessed 17 September 2020]

VOA Asia - Trump pulls U.S. out of Iran nuclear deal as North Korea summit looms (2018, May 8). Voice of America. Retrieved from: https://www.voa news.com/episo de/voa-asia-trump-pulls-us-out-iran-nuclear-deal-north-korea-summit-looms-20133 96. [Accessed 9 July 2020]

VOA60 World PM - Trump withdraws US from Iran nuclear deal (2018, May 8). Voice of America. Retrieved from: https://www.voanews.com/episo de/voa60-world-pmtrump-withdraws-us-iran-nuclear-deal-3778506. [Accessed 9 July 2020]

With Iran deal withdrawal, US officially becomes 'a rogue nation' (2018, May 9). Press TV. Retrieved from: https://www.presstv.com/Detail/2018/ 05/09/561146/With-Irandeal-withdrawal-US-officially-becomes-a-rogue-nation. [Accessed 8 July 2020]

Yeranian, E. (2018, May 9). Gulf allies applaud Trump decision to scrap Iran nuclear deal. Voice of America. Retrieved from: https://www.voanews.com/middle-east/gulf-alli es-applaud-trump-decision-scrap-iran-nuclear-deal. [Accessed 9 July 2020] 


\title{
Using Smartphone as a Journalistic Tool: An Examination of Ethical Codes in Mobile Journalism in Saudi Arabia
}

\begin{abstract}
By Ahmed Deen * \& Po-Lin Pan
This study aimed to understand the impact of ethical codes on Saudi journalists' perceptions toward mobile journalism (MOJO). Three major ethical dimensions were examined, including seeking truth, minimizing harm, and being accountable in news coverage. A survey link created with SurveyMonkey was transmitted via social media avenues, such as Twitter and WhatsApp, where Saudi journalists can complete the questionnaire and then share the link with other Saudi journalists. A total of 124 Saudi journalists were recruited by this snowball sampling approach, while the Codes of Ethics of Society of Professional Journalists was adapted as major measurements for three ethical dimensions, including seeking truth, minimizing harm, and being accountable. Results found that all three ethical dimensions of professional journalists generated significant influences on Saudi journalists' perceptions toward MOJO. Specifically, minimizing harm was found as the most powerful factor that affected Saudi journalists' perceptions toward MOJO, followed by being accountable and seeking truth, indicating that Saudi journalists who were more likely to seek truth, minimize harm, and be accountable would exhibit more positive perceptions toward MOJO. Although using smartphone as a journalistic tool was a key factor toward Saudi journalists' MOJO perceptions, it was not as powerful as three ethical dimensions that affected their MOJO perceptions.
\end{abstract}

Keywords: mobile journalism, codes of ethics, professional journalism, Saudi journalists

\section{Introduction}

Journalism has gone through a major change and benefited as a result of various technological discoveries over the last decade, which demonstrates that traditional journalism is conforming to constant change and news media can meet audience expectation, specifically in terms of credibility and timing (Maccise and Marai, 2016). Mobile Journalism (MOJO) is defined as a kind of digital storytelling where the primary device is used for writing, designing, and editing images. MOJO is considered a new phenomenon for multimedia storytelling where journalists are well trained and equipped for being fully mobile and completely autonomous (Myllylahti, 2017).

According to the Global Media Insight (2018), the population of Saudi Arabia reached 33.25 million in 2018, and the number of internet users in Saudi Arabia

*Doctoral Student in Mass Communication, School of Media Arts \& Studies, Ohio University, USA.

"Professor, Department of Communication, Arkansas State University, USA. 
rose swiftly to reach 30 million people at the beginning of 2018. The internet penetration in the country has now reached $91 \%$, and the number of social media usage on their mobile devices reached to 18 million, indicating $54.14 \%$ of Saudi Arabian population. Due to these increasing numbers and technological developments, the emergence of smartphones, along with digital technology and $\mathrm{Wi}-\mathrm{Fi}$, continues to change traditional journalism. Not only have smartphones become a crucial device for news consumption, but also provided a pocket-sized media hub for journalists. Therefore, mobile devices can be an alternative tool to traditional news outlets in Saudi Arabia. MOJO is a new era for journalism in Saudi Arabia when numerous Saudi journalists use mobile devices as their journalistic tools. The use of MOJO requires special equipment and news applications and programmers, which would generate some side effects on journalism practices, especially from an ethical perspective.

The role of ethical codes is key to news performance. Journalists produce their news stories based on the ethical codes of professional journalists. Media ethics around the world affirm that professional journalists should be committed to news truth, accuracy, honesty, integrity, and non-distortion of information (Abu Arqoub, 2010). Indeed, media ethics are issued to set journalism profession and play a primary role in covering news stories in a practical way. Therefore, this study aimed to explore how Saudi journalists would perceive MOJO based upon their consideration of ethical codes of professional journalists. Three major ethical codes were investigated in this study, namely seeking truth, minimizing harm, and being accountable in news coverage. More specifically, the study attempted to examine the extent to which Saudi journalists would seek truth minimize potential harm, and be accountable in news coverage in response to their MOJO perceptions. Moreover, three demographic variables, including Saudi journalists' news industry experiences, frequency of using smartphones as a journalistic tool, and education levels, were employed as key factors toward their MOJO perceptions. Simply stated, the study would offer practical insights into how Saudi journalists perceived MOJO based upon their considerations of ethical codes of professional journalists and their journalistic and technological experiences.

\section{Literature Review}

\section{Mobile Journalism}

Mobile Journalism (MOJO) is a creation of the modern technology, especially the use of the mobile technology for the video journalism purposes (Karhunen, 2017). MOJO is the process by which information is collected and disseminated to the society, through the use of the mobile technology, and even the use of the tablets (Maccise and Marai, 2016). MOJO is mainly used in the process of news reporting and delivering through mobile devices in order to enhance the coverage of breaking news.

MOJO is a modern process that facilitates the media workflow and storytelling process, in which journalists are offered with the basic training and equipped to 
move from one place to another with independence. Although most journalists have integrated the use of the laptops into the processing of news coverage, the use of mobile phones has remained as an eternity of the essential ways through which a majority is able to advance in the journalism sector.

MOJO is also used for radio news and podcasts, television news and documentaries, and even videos for social platforms. Indeed, MOJO is a new workflow for media storytelling where reporters are trained and equipped for being fully mobile and fully autonomous (Mobile Journalism Manual, 2018). MOJO is more focused on enhancing the empowerment process of individual storytellers who can use the consumer technology to come up with the best story possible. Thus, the definition of MOJO can be extended to include DSLR cameras, laptops, GoPros, and even mobile phones.

MOJO is one of the fastest growing sections within the modern journalism industry, although there is a major problem facing mobile journalists, especially the tension that exists between the various issues of print, broadcast as well as digital journalism, traditional journalism and lifestyle journalism (Fürsich, 2012). MOJO is becoming increasingly, one of the most important sectors, not only in news media industry, but also on other sectors, such as organizations that need to capture the various live activities, like NGOs, PR agencies, broadcasting and even social media specialists (Perreault and Stanfield, 2019). According to Maccise and Marai (2016), new ideas in the journalism industry are brought into light by individuals who are using their mobile devices to generate information. Due to MOJO, most journalists are able to enhance their skills and ensure their interests to explore an alternative medium better than others that had been used in traditional journalism. MOJO is embraced by various editors and even managers who are in charge of the process of enhancing news development and practice. However, it is important to investigate whether journalists are trained well to use mobile devices for the purposes of news reporting, where the technical competencies must be accompanied by the various key journalistic skills, including their ability of storytelling, justification of information, verification, and even packaging of the content collected for mobile devices.

Podger (2018) explained that several benefits are attributed by MOJO, given that smartphones can be used in various ways, such as the production studio for radio, television production, text production and even the creation of social content in one's pockets. These benefits include: Affordable, Portable, and Discreet. Affordable indicates that the smartphones can be used in the creation of the television-quality video if the video is created with the use of professional video recording app, and the addition of the external microphone and tripod. Using that set-up, there is the grate minimization of costs, given that it does not cost the same as having an entry-level TV camera. The process makes it possible and affordable for the millions of people across the world to receive news, through multimedia storytelling process, especially for journalists and storytellers working in NGOs, education sector, or business sectors. Portable means that the majority of journalists can fit their equipment in a backpack, since phone, lightweight tripod, clip-microphones, and external light have a weight under three kilograms, hence, making the process of high-quality storytelling production easy and effective. 
Discreet denotes that the availability makes mobile phones an ideal tool for most journalists to sue across the world, and the need to have a discreet use of mobile devices, when covering news stories (Podger, 2018).

The impacts of new technologies on professional journalism are deterministic. As new technologies were used as key tools to direct professional journalism into a dialogical and participatory model of journalism, everyone who can produce and deliver short videos via new technologies can be journalists (Kawamoto, 2003; O' Sullivan, 2005). Some empirical studies investigated the impacts of new technologies on the practices of professional journalism. Urshell (2001) found that the use of new technologies in professional journalism is dependent on the goals and judgments of executive personnel and political regulators. Although journalists tend to acknowledge dialogical and participatory attributes of new technologies (Hermida and Thurman, 2008), they are still uncertain to embrace this dialogical and participatory model in their journalism practices (Heinonen, 2011). Specifically, reluctance to surrender control (Singer and Gonzalez-Velez, 2003; O' Sullivan, 2005), extra workload and difficulties in moderating and controlling user-generated content (Thurman, 2008; Chung, 2007), lack of necessary innovative skills (O’ Sullivan 2005; Robinson, 2011; Brannon, 2008) and a rigid professional culture rooted in established journalistic routines and professional beliefs (Ryfe, 2009) are key factors delaying the use of new technologies in professional journalism. Furthermore, Spyridou et al. (2013) found that the use of new technologies is seen as empowering journalists to do their traditional jobs better instead of moving on to the dialogical and participatory model of journalism built around a stronger commitment to capitalize on the growing sociotechnical potential.

Correspondingly, some negative impacts of new technologies on MOJO were deterministic. For example, Blankenship (2016) found that the mobile journalists have less specialized expert knowledge. Although working outside a crew gives them greater autonomy, their increased use of work routines makes them to give up some control to organizational needs. Moreover, these mobile journalists allow some encroachments by other professionals, specifically public relations professionals, in order to accomplish their work tasks within specified deadlines with limited time and resources. Similarly, Kumar and Haneef (2018) found that the practice of MOJO leads journalists to learn new apps and tools, produce short videos by and for mobile devices, and disseminate news to digital readers through multiple platforms, but also discourages journalists to value basic news reporting and gathering skills.

\section{Smartphones for MOJO}

The popularity of smartphones is attributed to the universality and manner in which they are available in the market and different societies. Smartphones are small of size with better processing and connectivity capabilities, have reduced the cost of operation, and have the ability to host several multi-goal applications. The modern smartphones can harbor multimedia technologies, high-capacity sensor data, various communication logs, retention of data created or even consumed by 
various applications, among others. Smartphone is utilized for state-of-the-art mobile phone devices, by industry and research community. Smartphones are regarded as 'smart' due to a major difference from regular phones and cellphones which are not technologically enabled. Also, smartphones are devices that have two characteristics. First, each smartphone contains a mobile network operator smartcard that enables the phone to have a connection to mobile networks, in the form of SIM or USIM card in the GSM and UMTS systems. The second aspect is that all smartphones have an operating system that has the ability to link with any third-party software (Theoharidou et al., 2012).

According to Budmar (2012), smartphones are more similar to handheld personal computers with the ability to enhance extensive computing capabilities, the inclusion of the high rates of speed, the power to access the Internet, through the Internet and mobile broadband. A majority of smartphones is built with the ability to support Bluetooth and Satellite Navigation Systems, which give the users the ability to access services through touchscreen color display option and also provide the users with the ability to enhance the graphical interface that can cover the front surface and virtual keyboard, where it is possible to type and even press the onscreen icons. Also, all interactions are mostly done through the use of touchscreen, although there exists a few physical buttons (Budmar, 2012). Smartphones are usually small, fitting comfortably in the pockets of the users, although there are larger ones, known as the phablets which are smaller than tablet computers. Moreover, smartphones use a lithium-ion battery which is mostly rechargeable.

Mohd (2013) suggested that smartphones show a combination of personal device assistants as well as mobile phones that focus on using advanced operating systems, while permitting the users to be able to make the installation of new applications, the ability to connect to the internet, and enhance the provision of varied functionalities of two aspects of phones. Smartphones make the lives of many people better and easier since the use of the Internet is part of people's everyday life, where within 24 hours a day, people use the Internet for their various activities. The application of mobile devices that are equipped with digital access and camera as well as messaging services becomes a key inspiration for the use of mobile devices in growth in covering news stories. The technological innovation further enhances the development of general processes, leading a majority of journalists working for several media houses and using mobile devices to cover news stories. The use of mobile devices also leads to a rapid growth in modern citizen journalism. The use of MOJO promotes the expansion of mobile technologies and new opportunities for journalism. The process has influenced on the issue of mobile news reporting, which impacts the general organization and the practice of journalism, where certain mobile device features, such as positioning, are able to receive specific attention. Moreover, the use of MOJO is effective, given that it cuts costs, enhances the usability and functionality, and minimizes journalistic challenges (Jokela et al., 2009).

The Reuters news agency seeks an opportunity for MOJO and enters into a contract with the Finnish Nokia Company, so as to enhance the development of a model for digital journalism. This idea gives birth to the emergence of mobile 
devices that lead to small computers with permanent and specific applications. Smartphones are giving the world another aspect of journalism. With the modern introduction of various means of communication, such as satellite, terrestrial or microwave, the flow of communications becomes easier and effective, both in the local and international arena, due to the links with newer technologies and other media, such as telex and facsimile (Bivens, 2008).

\section{Ethical Codes of Professional Journalists}

Media ethics in various media channels, such as print, audio, video, and electronic media, are viewed as the most important component for media performance (Al-Abad, 2017). Many Press Associations have drafted media codes of ethics to be a moral guide for journalists to set their performance for media audiences. For example, the Jordanian Press Association has issued its first code of ethics in 1996 and the second code of ethics by the late of 2003 (Abu Arqoub, 2010). Abu Arqoub (2010) continued to emphasize that the freedom of speech, journalists' right to receive information, and journalists not to obtain special benefits are highly considered and specified at the second draft of the Jordanian media code of ethics. The main purpose of drafting the media code of ethics is to reduce the governmental control over media outlets. Makharesh (2018) stated that media outlets are strictly controlled by states and the journalism practice that aims to search and uncover the truth is observed as strange in the Arab world.

The Code of Ethics of Society of Professional Journalists is the biggest national journalism organization of the Society of Professional Journalists, whose main function is to promote the process of free journalism practices and the process of stimulating the high-level standards of the journalist's ethical behavior. The organization was founded in 1909, with the name Sigma Delta Chi, SPJ, and promoted the process of free information flow which was critical for the creation of a citizen who were well-informed, through the daily activities of almost 7,500 members, where the main focus was to inspire and also educate the journalists, both in the present and the future, through the process of professional development. The organization also protected the First Amendment, which gave the journalists the guarantee of the freedom of speech and the press by the advocacy efforts (Society of Professional Journalists, 2014).

The Society of Professional Journalists Code of Ethics is a statement of abiding principles supported by The Society of Professional Journalists, the nation's most broad-based journalism organization that is dedicated to encouraging the free practice of journalism and stimulating high standards of ethical behavior. Founded in 1909 as Sigma Delta Chi, SPJ promotes the free flow of information vital to a well-informed citizenry through the daily work of its nearly 7,500 members; works to inspire and educate current and future journalists through professional development; and protects First Amendment guarantees of freedom of speech and press through its advocacy efforts (Society of Professional Journalists, 2014).

This study attempts to look at three key dimensions of the Code of Ethics of Society of Professional Journalists, namely Seeking Truth, Minimizing Harm, and Being Accountable. These three dimensions are selected in response to Saudi 
journalists' perceptions toward MOJO, given that these dimensions are highly related to the core value of professional journalism that promotes accuracy, humanity, and accountability (Harcup, 2020), and could be gradually disregarded when mobile journalists have to complete their work tasks within specified deadlines with limited time and resources (Blankenship, 2016). The study examines how these ethical dimensions affect Saudi journalists' perceptions toward MOJO and which dimension generates a greater impact on their perceptions toward MOJO. Moreover, three demographic factors are considered as key variables that influence Saudi journalists' MOJO perceptions, including their news industry experiences, frequency of using smartphone as a journalistic tool, and education levels. Six research questions were proposed in the following:

RQ1: Do Saudi journalists who are more inclined to seek truth in their news coverage have more positive perceptions toward MOJO?

RQ2: Do Saudi journalists who are more inclined to minimize potential harm in news coverage have more positive perceptions toward MOJO?

RQ3: Do Saudi journalists who are more accountable in news coverage have more positive perceptions toward MOJO?

RQ4: Do Saudi journalists with more news industry experiences have more positive perceptions toward MOJO?

RQ5: Do Saudi journalists with more experiences in using smartphone to cover their news stories have more positive perceptions toward MOJO?

RQ6: Do Saudi journalists' education levels influence their perceptions toward MOJO?

\begin{abstract}
Methods
This study aimed to better understand the impact of ethical codes on Saudi journalists' perceptions toward MOJO. Three major variables related to ethics were examined in this study, including seeking truth in news coverage, minimizing harm, and being accountable. A computer-mediated questionnaire was developed by the researchers. This online questionnaire was transferred on a program installed into the computer, known as the computer-assisted self-administered interviewing, to the participants as an email link. The online questionnaire was conducted to explore Saudi journalists who were residents of the Kingdom of Saudi Arabia. The survey was first written in English, and later translated into Arabic language.
\end{abstract}

\title{
Sampling and Procedure
}

Snowball sampling approach was used for the study which applied the principle of chain referral, where the participants are requested to choose and even bring an extra individual into the study population. The approach, therefore, was used for the selection of the required number of Saudi journalists who were accessible. The major assumption for snowball sampling was that all the members of the target group knew each other to create a sampling frame. The sampling 
process was also sued in the processes of studying the deviant behavior, where the issues of morality, legality or social sensitivities of a given behavior were discussed. The ideal candidates to participate in this online questionnaire were obtained through the chain process and the development of the initial conducts for referrals determined the quality of the sample and representation of the actual population. Regarding the distribution of online questionnaire, the link would be shared by the participants' permission after completing the survey and passing it to other potential candidates. The participants would be told that their participation was voluntary, and all personal information was destroyed after data collection. Finally, the data was transferred into Statistical Package for the Social Sciences (SPSS) for the final analysis.

\section{Measured Variables}

The link created with SurveyMonkey was transmitted via social media avenues, such as Twitter and WhatsApp, where the participants can complete an online survey based on three advantages: Anonymity, flexibility, and volunteerism. Due to the nature of mother tongue of Arabian participants, the questionnaire was translated into Arabic language. The questionnaire was divided into several sections, based on research questions. The questions also provided with a form of multiple choices, which included gender, level of education, age, opinions and behaviors, and ranking the most truth source for news by the participants. Age group was divided into four categories, including: (1) 18-25, (2) 26-32, (3) 33-39, and (4) 40 and over. Four major variables were examined in the following.

Seeking Truth in News Coverage. Six items were used to measure the extent to which Saudi journalists sought truth in news coverage. These items included: (1) I test the accuracy of information from all sources in my news coverage, (2) I identify the sources whenever feasible in my news coverage, (3) I always question source motives before promising a anonymity in my news coverage, (4) I never distort the content of news photos or video image enhancement in my news coverage, (5) I never plagiarize in my news coverage, and (6) I avoid any stereotypes in news coverage. Five-point scales were used to assess their responses $(1=$ Strongly Disagree; $5=$ Strongly Agree $)$. All scores were summed and averaged $(M=4.27, S D=0.65)$. Cronbach's alpha for this measure was 0.81 .

Minimizing Harm in News Coverage. Six items were included to measure the extent to which Saudi journalists minimized potential harm through their news coverage. These items were: (1) I show compassion for those whom may be affected by my news coverage, (2) I am sensitive when seeking or using interviews of those affected by tragedy in my news coverage, (3) I recognize that gathering and reporting information may come harm of discomfort in my news coverage, (4) I show the good taste when covering news, (5) I am cautions about identifying juvenile suspects in my news coverage, and (6) I balance a criminated suspects fair tried rights with the epacts' rights to be informed in my news coverage. Five-point scales were used to evaluate their responses. All scores were summed and averaged $(M=4.25, S D=0.54)$. Cronbach's alpha for this measure was 0.72 . 
Accountability in News Coverage. Five items were utilized to measure the extent to which Saudi journalists were accountable in news coverage. These items were: (1) I clarify and explain my news coverage and invite dialogue with the public, (2) I encourage the public to voice grievances against the news media, (3) I admit my mistake and correct them promptly, (4) I expose unethical practices of journalists and the news media, and (5) I abide by the same high standards they expect of others. Five-point scales were used to assess their responses and all scores were summed and averaged $(M=4.30, S D=0.56)$. Cronbach's alpha with the current sample was 0.68 .

Saudi Journalists' MOJO Perceptions. Seven items were applied to measure how Saudi journalists perceived MOJO. These items were: (1) the mobile journalism is the process by which information is collected to the society, through the use of the mobile technology, (2) mobile journalism is been used majorly in the process of covering news and broadcasting, (3) mobile journalism is considered the modern process of journalism, (4) the mobile journalism is one of the fastest growing styles within the modern journalism industry, (5) the mobile journalism allows journalists to explore alternative mediums in their journalistic work, (6) mobile journalism makes creating content easier at any time more than traditional journalism, (7) the availability of the smartphones facilitates the journalists' efforts to report news across the world. Five-point scales were used to assess their answers. All scores were summed and averaged $(M=4.49, S D=$ 0.59). Cronbach's alpha with the current sample was 0.87 .

\section{Results}

\section{Participants}

A total of 124 Saudi journalists participated in this online questionnaire, but only 115 participants were retained, given that nine participants did not complete the questionnaire. As indicated in Table 1, a total of 79 males $(73.8 \%)$ and 25 females (26.2\%) participated in this study. Regarding journalistic experiences, 43 participants who had worked for 4 to 10 years $(40.2 \%)$, followed by 28 participants for 11 years and more, (26.2\%), 25 participants for 1 to 3 years (23.4\%) and 11 participants worked for less than one year (10.3\%). For journalists who used smartphone as a journalistic tool to cover news stories, a total of 55 participants used smartphones for news coverage for 1-3 years $(51.4 \%)$, followed by 28 participants for 4-6 years (26.2\%), 18 participants for less than one year (16.8\%), and 6 participants for $7-11$ years (5.6\%). Regarding age, 39 participants were aged from 26 to 32 (36.4\%), followed by 28 aged from 33 to 39 (26.5\%), 21 aged from 18 to $25(19.6 \%)$, and 19 aged at 40 and more (17.8\%). As to education levels, 71 participants acquired a bachelor's degree (66.4\%), 34 held a graduate degree (31.8\%), and only 2 finished high school (1.9\%). 
Table 1. Demographics

\begin{tabular}{|l|c|c|}
\hline & N & $\%$ \\
\hline Gender & & 72.8 \\
\hline Male & 79 & 26.2 \\
\hline Female & 25 & \\
\hline News Industry Experience & 11 & 10.3 \\
\hline Less than one year & 25 & 23.4 \\
\hline $1-3$ years & 43 & 40.2 \\
\hline $4-10$ years & 28 & 26.2 \\
\hline 11 years and more & 18 & \\
\hline Smartphone as News Tool Experiences & 55 & 16.8 \\
\hline Less than one year & 28 & 51.4 \\
\hline $1-3$ years & 6 & 26.2 \\
\hline $4-6$ years & & 5.6 \\
\hline $7-11$ years and more & 21 & 19.6 \\
\hline Age Group & 29 & 36.4 \\
\hline $18-25$ & 28 & 26.2 \\
\hline $26-32$ & 19 & 17.8 \\
\hline $33-39$ & & 1.9 \\
\hline 40 and more & 2 & 66.4 \\
\hline Education Level & 71 & 31.8 \\
\hline High School & 34 & \\
\hline Bachelor's & & \\
\hline Graduate & & \\
\hline
\end{tabular}

RQ1 was proposed to examine the impact of seeking truth in news coverage on Saudi journalists' perceptions toward MOJO. As indicated in Table 2, the results showed a significant positive relationship between seeking truth in news coverage and perceptions toward MOJO $(r=0.52, p<0.01)$, indicating that Saudi journalists who were more likely to seek truth in news coverage would exhibit more positive perceptions toward MOJO. Specifically, as indicated in Table 3, seeking truth was loaded in the third stepwise regression model $(B=0.21, t=2.12$, $p<0.05$ ), but less powerful than minimizing harm and being accountable to influence Saudi journalists' perceptions toward MOJO.

RQ2 looked at whether the impact of minimizing harm in news coverage on Saudi journalists' perceptions toward MOJO. Table 2 also suggested that Saudi journalists who were more inclined to minimize harm to others in news coverage would perceive MOJO as more positive $(r=0.55, p<0.01)$. Moreover, Table 3 showed that minimizing harm was loaded in the first $(B=0.55, t=6.93, p<0.01)$, second $(B=0.40, t=4.43, p<0.01)$ and third $(B=0.31, t=3.19, p<0.01)$ stepwise regression models, which further suggested that minimizing harm in news coverage was the most important factor toward Saudi journalists' perceptions toward MOJO. 
Table 2. Correlation Matrix

\begin{tabular}{|c|c|c|c|c|c|c|c|}
\hline \multicolumn{2}{|c|}{ Variable } & 2 & 3 & 4 & 5 & 6 & 7 \\
\hline 1. & Perceptions of MOJO & $0.52^{* *}$ & $0.55^{* *}$ & $0.49^{* *}$ & -0.06 & $-0.22^{\text {** }}$ & -0.09 \\
\hline 2. & Seeking Truth & - & $0.59^{* *}$ & $0.57^{* *}$ & -0.04 & $-0.21^{*}$ & 0.06 \\
\hline 3. & Minimizing Harm & & - & $0.53^{* *}$ & -0.06 & $-0.16^{*}$ & -0.01 \\
\hline 4. & Being Accountable & & & - & -0.002 & -0.08 & $-0.21^{*}$ \\
\hline 5. & News Industry Experiences & & & & - & $0.55^{* *}$ & $0.30^{\text {*** }}$ \\
\hline 6. & Smartphone as Journalistic Tool & & & & & - & 0.13 \\
\hline 7. & Education Levels & & & & & & - \\
\hline
\end{tabular}

Note: ${ }^{*} p<0.05 ;{ }^{* *} p<0.01$

Table 3. Stepwise Regression Models

\begin{tabular}{|c|c|c|c|c|c|c|}
\hline & \multicolumn{6}{|c|}{ Model Statistics } \\
\hline & \multicolumn{2}{|c|}{ Model $1^{* * 1}$} & \multicolumn{2}{|c|}{ Model $2^{* * 2}$} & \multicolumn{2}{|c|}{ Model3**3 } \\
\hline$F$ & \multicolumn{2}{|c|}{48.01} & \multicolumn{2}{|c|}{31.03} & \multicolumn{2}{|c|}{5.26} \\
\hline$R^{2}$ & \multicolumn{2}{|c|}{0.30} & \multicolumn{2}{|c|}{0.36} & \multicolumn{2}{|c|}{0.38} \\
\hline$R^{2}$ Change & \multicolumn{2}{|c|}{0.30} & \multicolumn{2}{|c|}{0.06} & \multicolumn{2}{|c|}{0.03} \\
\hline Variable & $\begin{array}{c}\text { Standardized } \\
\text { Beta }\end{array}$ & $t$ & $\begin{array}{c}\text { Standardized } \\
\text { Beta }\end{array}$ & $t$ & $\begin{array}{c}\text { Standardized } \\
\text { Beta }\end{array}$ & $t$ \\
\hline Seeking Truth & & & & & 0.21 & $2.12^{*}$ \\
\hline Minimizing Harm & 0.55 & $6.93^{* *}$ & 0.40 & $4.43^{* *}$ & 0.31 & $3.19^{* *}$ \\
\hline Being Accountable & & & 0.28 & $3.19^{* *}$ & 0.21 & $2.21^{*}$ \\
\hline News Industry Experiences & & & & & & \\
\hline Smartphone as Journalistic Tool & & & & & & \\
\hline Education Levels & & & & & & \\
\hline
\end{tabular}

Note: ${ }^{*} p<0.05 ;{ }^{* *} p<0.01 ;{ }^{1}$ Predictor Included: Minimizing Harm; ${ }^{2}$ Predictors Included: Minimizing Harm and Being Accountable; ${ }^{3}$ Predictors Included: Minimizing Harm, Being Accountable, and Seeking Truth. 
RQ3 was proposed to explore the impact of being accountable in news coverage on Saudi journalists' perceptions toward MOJO. The results found a positive relationship between being accountable in news coverage and perceptions toward MOJO ( $r=0.49, p<0.01)$, indicating that Saudi journalists who were more accountable in news coverage would exhibit more positive perceptions toward MOJO. Additionally, being accountable was loaded in the second $(B=0.28, t=$ $3.19, p<0.01)$ and third $(B=0.21, t=2.21, p<0.05)$ stepwise regression models, indicating that being accountable was more powerful than seeking truth, but less essential than minimizing harm toward Saudi journalists' MOJO perceptions.

RQ4 examined whether Saudi journalists' news industry experiences affected their perceptions toward MOJO. The results did not find any significant relationship between news industry experiences and MOJO perceptions $(r=-0.06$, $p=0.26)$. On the other hand, RQ5 was used to explore the impact of using smartphone as a journalistic tool on Saudi journalists' perceptions toward MOJO. The results showed a negative relationship between using smartphone as a journalistic tool and MOJO perceptions $(r=-0.22, p<0.05)$, indicating that Saudi journalists who adopted smartphones to cover news stories less frequently would exhibit more positive perceptions toward MOJO. Finally, RQ6 examined the impact of Saudi journalists' education levels on their perceptions toward MOJO. The results did not show any significant influence of education levels on their MOJO perceptions $(r=-0.09, p=0.17)$. Moreover, three demographic factors were not loaded in any stepwise regression models, demonstrating that these demographic factors were not as powerful as three ethical variables that affected how Saudi journalists perceived MOJO.

\section{Conclusion}

In spite of the significance of MOJO in Saudi Arabia, there are very limited studies that examined how Saudi journalists would perceive mobile journalism based upon key ethical dimensions of professional journalists. The study found that all three key ethical dimensions generated significant influences on Saudi journalists' perceptions toward MOJO. Specifically, Saudi journalists who were more likely to seek truth, minimize harm, and be accountable in their news coverage would perceive MOJO as more positive, which suggested that MOJO can be perceived to meet the standard of ethical codes of professional journalists. Moreover, as three dimensions of ethical codes affected how Saudi journalists perceived MOJO at various levels, minimizing harm played the most powerful role in influencing Saudi journalists' perceptions toward MOJO. Indeed, Saudi Arabia is a society intertwined with collectivism culture in accordance with their social norms and religious customs. The value of minimizing harm may become the most important standard when Saudi journalists defined MOJO as their profession.

Being accountable was another key standard to perceive MOJO in Saudi journalists, as it was less powerful than minimizing harm, but more significant than seeking truth. This may explain that journalism ethics in Saudi Arabia should 
cultivate Saudi journalists to take more responsibility for their journalistic works that decidedly generated impacts on the public, which should be applied in MOJO too. Moreover, Saudi journalists were admitted by their news organizations to acknowledge their mistakes, but they must correct these mistakes promptly and prominently. The policy of the ministry of media also issued certain media legislations to promote responsible news media. Thus, it is fair to state that the value of being accountable should be an essential standard when Saudi journalists perceived MOJO.

Seeking truth was an important ethical dimension, but it was the least important standard to perceive MOJO. Indeed, the definition of truth can be varied by different news ideologies, especially when most news organizations were more likely to set their own agendas. In Saudi Arabia, news organizations were endowed by particular professional sports teams. They reported these teams in very positive ways and sports journalists who worked in these news organizations were hired to support sports clubs/teams. Thus, media bias emerged in most Saudi journalists, which may affect Saudi journalists to evaluate the value of seeking truth less important than those of minimizing harm and being accountable when they perceived MOJO.

News industry and the education levels, as two key demographic variables, did not produce any influences on Saudi journalists' perceptions toward MOJO. It may explain that Saudi journalists did not specialize in any journalism field and a large number of Saudi journalists were part-time journalists. This demonstrated that the impact of education levels and news industry would not affect how Saudi journalists used smartphones for their news coverage and how they perceived MOJO as their profession. Instead, Saudi journalists' frequency of using smartphone as a journalistic tool would cultivate them to be more skilled at mobile technologies and assist them to be more professional mobile journalists.

Although several insights were generated, some limitations still emerged. First of all, several participants indicated that there were many questions in the questionnaires. Some did lose their patience and skip some questions, while several Saudi journalists did not complete the questionnaires, which resulted in a major limitation for this study. Second, the sample may also restrict the generalization of the results in this study. As stated previously, most valid samples were male journalists. Therefore, the sample may not generalize the population appropriately. Future research may examine how gender differences would influence Saudi journalists' perceptions toward MOJO and whether gender difference would vary significantly to mediate the impact of ethical dimensions of professional journalists on their perceptions toward MOJO.

Finally, some personality traits may play another key role in Saudi journalists' perceptions toward MOJO, beyond the ethical codes of professional journalists. Future research could investigate personality traits as predictors toward how Saudi journalists would perceive MOJO. Moreover, this study found a positive relationship among seeking truth, minimizing harm, being accountable and Saudi journalists' perceptions toward MOJO, but the study did not look at some interaction effects between personality predictors and other ethical variables on Saudi journalists' perceptions toward MOJO. Future research may focus on the 
impacts of other personality traits related to Saudi journalistic norms and examined whether Saudi journalists at various levels of these personality traits would lead to different levels of MOJO perceptions based upon their consideration of ethical codes.

\section{References}

Abu Arqoub, M. (2010). The attitudes of Jordanian journalists toward the code of ethics. Amman, Jordan: Middle East University.

Al-Abad, Z. (2017). Media ethics need to be regulated. Retrieved from: http://www.alku waityah.com/Default.aspx. [Accessed 20 September 2018]

Bivens, R. K. (2008). The Internet, mobile phones and blogging. Journalism Practice 2(1), 113-129.

Blankenship, J. (2016). Losing their "MOJO"? Mobile journalism and the deprofessionalization of television news work. Journalism Practice, 10(8), 1055-1071.

Brannon, J. (2008). Maximize the medium: assessing obstacles to performing multimedia journalism in three US newsrooms, In C. Paterson, D. Domingo (eds.), Making Online News: The Ethnography of New Media Production, 99-111. New York: Peter Lang.

Budmar, P. (2012). Why Japanese smartphones never went global. Retrieved from: https:// www.pcworld.idg.com.au/article/430254/why_japanese_smartphones_never_went_g lobal. [Accessed 25 September 2018]

Chung, D. S. (2007). Profits and perils: online news producers' perceptions of interactivity and uses of interactive features. Convergence, 13(1), 43-61.

Fürsich, E. (2012). Lifestyle journalism as popular journalism: strategies for evaluating its public role. Journalism Practice, 6(1), 12-25.

Global Media Insight (2018). Saudi Arabia social media statistics 2018. Retrieved from: https://www.globalmediainsight.com/blog/saudi-arabia-social-media-statistics/. [Accessed 20 September 20 2018]

Harcup, T. (2020). What's point of news? A study in ethical journalism. Switzerland: Palgrave Macmillan.

Heinonen, A. (2011). The Journalists' Relationships with users - New dimensions to conventional roles. In J. Singer, D. Domingo, A. Heinonen, A. Hermida, S. Paulussen, T. Quandt, et al. (eds.), Participatory Journalism, 34-55. Wiley-Blackwell.

Hermida, A., Thurman, N. (2008). A clash of cultures: the integration of user-generated content within professional journalistic frameworks at British newspaper websites. Journalism practice, 2(3), 343-356.

Jokela, T., Väätäjä, H., Koponen, T. (2009). Mobile journalist toolkit: a field study on producing news articles with a mobile device. In Proceedings of the $13^{\text {th }}$ International MindTrek Conference: Everyday Life in the Ubiquitous Era, 45-52. ACM.

Karhunen, P. (2017). Closer to the story? Accessibility and mobile journalism. Oxford, UK: University of Oxford.

Kawamoto, K. (2003). Digital Journalism - Emerging Media and the changing horizons of journalism. Lanham: Rowman and Littlefield Publishers.

Kumar, A., Haneef, M. S. H. (2018). Is Mojo (en)de-skilling? Journalism Practice, 12(10), 1292-1310.

Maccise, D. L., Marai, M. (2016). Mobile journalism. Doha: Al Jazeera Media Institution.

Makharesh, A. (2018). Arab citizen's perceptions of the investigative journalism. ProQuest Dissertations \& Theses Global. Retrieved from: https://dbellis.library.astate.edu/vwe bv/holdingsInfo?bibId=3016309. [Accessed 25 September 2018] 
Mobile Journalism Manual (2018). How we understand mobile Journalism. Retrieved from: http://www.mojo-manual.org/understanding-mobile-journalism/. [Accessed 25 September 2018]

Mohd, S. N. (2013). Students' demand for smartphones: structural relationships of product features, brand name, product price and social influence. Campus-wide Information Systems, 30(4), 236-248.

Myllylahti, M. (2017). The rise of tactical partnerships: media converging beyond ownership. MEDIANZ: Media Studies Journal of Aotearoa New Zealand, 17(1): 74 90.

O'Sullivan, J. (2005). Delivering Ireland: journalism's search for a role online. Gazette: The International Journal for Communication Studies, 67(1), 45-68.

Perreault, G., Stanfield, K. (2019). Mobile journalism as lifestyle journalism? Journalism Practice, 13(3), 331-348.

Podger, C. (2018). Mobile journalism and digital storytelling. Retrieved from: http://voices .media/corinne-podger-mobile-journalism-digital-storytelling. [Accessed 20 September 2018]

Robinson, S. (2011). Convergence crises: news work and news space in the digitally transforming newsroom. Journal of Computer-Mediated Communication, 61(6), $1122-1141$.

Ryfe, D. (2009). Broader and deeper: a study of newsroom culture in a time of change. Journalism, 10(2), 197-216.

Singer, J. B., Gonzalez-Velez, M. (2003). Envisioning the caucus community: online newspaper editors conceptualize their political roles. Political Communication, 20(4), 433-452.

Society of Professional Journalists (2014). SPJ Code of Ethics. Retrieved from: https:// www.spj.org/ethicscode.asp. [Accessed 20 September 2018]

Spyridou, L. P., Matsiola, M., Veglis, A., Kalliris, G., Dimoulas, C. (2013). Journalism in a state of flux: journalists as agents of technology innovation and emerging news practices. International Communication Gazette, 75(1), 76-98.

Theoharidou, M., Mylonas, A., Gritzalis, D. (2012). A risk assessment method for smartphones. In IFIP International Information Security Conference, 443-456. Berlin, Heidelberg: Springer.

Thurman, N. (2008). Forums for citizen journalists? Adoption of user-generated content initiatives by online news media. New Media \& Society, 10(1):139-157.

Urshell, G. (2001). Dumbing down or shaping up? New technologies, new media, new journalism. Journalism, 2(2), 175-196. 



\title{
Investigation of Social Approaches in Different Countries towards Suicide of the Blue Whale Game through Newspaper News
}

\author{
By Ayşe Aslı Sezgin *
}

\begin{abstract}
The aim of this study is to examine the negative attitude and prejudice of the media reflected in news articles about the relationship between 'online games and suicidal youth'. This study analyzed the content of the news and the language of the media used for young people who committed suicide related to playing Blue Whale Challenge in different social settings. In this study, news articles in three different countries were examined with the content analysis method, using the content descriptors of Entertainment Software Rating Board (ESRB). In the news concerning young people who committed suicide and used this game, it was clearly observed that sources of influence involved attitudes towards online games, developed in part through the messages of the media, and that social conditions, including generational experiences, were influential in creating the media messages.
\end{abstract}

Keywords: media panic, violence, online games, Blue Whale Challenge

\section{Introduction}

Intergenerational differences have been an important subject of academic inquiry in the field of social sciences. Recent studies (Yang, 2008; Alwin, 2002; Jorgensen, 2003; Huang and Petrick, 2010) have classified generations as X, Y and $\mathrm{Z}$, according to the chronological order. The concept of cohorts refers to generations whose common features come to the fore in the social process.

The term 'cohort', which is often used to describe a group of people born in the same time frame, refers to people with similar age-related experiences and paths in life (Katz, 2017). In defining the generations, the definition of cohorts is, therefore, used with its specific characteristic. The concept of cohorts, which is used as a key concept in studies analyzing social change, refers to groups of different sizes in society, especially depending on age. This concept also indicates that. These groups generally go through the same social experiences (Nilsen, 2014).

In this context, when it comes to conducting a sociological classification, the characteristics of groups defined as Generations X, Y and Z have been highlighted in recent years. In this study, different generations are briefly explained in chronological order.

The main purpose of this study is to draw attention to negative attitudes and prejudices created by media messages on societies. One example of such negative

*Associate Professor, Department of Communication Sciences, Faculty of Communication, Çukurova University, Turkey. 
attitudes is related to the game called Blue Whale Challenge, which is perceived by people as reflected in the media, creating a panic atmosphere throughout the society. Here, the main concern is the media's point of view. For this reason, this study examined the media messages in particular in a variety of social settings. A considerable outcome obtained from the study is that just like the impact of social conditions on the process of creating media messages, social reactions are affected by media messages in a similar manner.

Computer-based online games have been a universal feature of popular culture in recent years. The set-up of reality in these games requires the use of the most complex software, hardware, animation and graphic design technologies with respect to the dramatic and fantastic environment, information and communication technology. Online games enable many people to play through the online network provided by PC communication services. Online games create an environment in which people can interact with each other by using graphics and audio technologies, allowing people to feel the excitement of the game while playing. Defined as games where many people can participate in online communication networks at the same time, online games enable players to interact directly with the game through a server (Hoon et al., 2002). The game called the Blue Whale Challenge is one of those in which interaction is the most intense. However, another important detail is the lack of information about the causes of violence and suicide. The way the media, which is an important source of information on the subject, reflects these events, clearly aims to create a panic atmosphere.

In the study conducted by Lindsay et al. (2014) on the spread of violence in the media content, violence was examined in various media contents. Violence in the media is briefly described as 'a clear depiction of a threat or a force that could harm' (Lindsay et al., 2014).

Additionally, the effect of violence on society was also examined in the same study, which stated that especially children and young people who are exposed to violence in the media content tend to exhibit more aggressive behavior than those who are not. Such young people and children may also get provoked more, depending on the extent of the panic atmosphere created by the media (Lindsay et al., 2014). Violence in the media also affects how people perceive the world and their reactions to events around them. Violence in the media content is also effective in emotional reactions of people when they encounter real violence (Lindsay et al., 2014). In this study, the negative language used for communicating the news about Blue Whale Challenge in the media is examined within the scope of the relationship between the media and violence.

\section{Literature Review}

\section{Generations X, Y and Z Definitions}

Generation X, which took its social aspects from the Baby Boomers, born in the late 1940s and early 1960s, represents those who were born in the late 1970s (Katz, 2017). The characteristics of Generation X can be defined as individuals 
who are autonomous, independent and prone to communication (Jorgensen, 2003). An evaluation made about Generation $X$ in the social context reveals a period in which social movements began to take place. Unlike Baby Boomers, Generation $\mathrm{X}$ represents a generation of families who began to face financial difficulties (Sandeen, 2008).

Furthermore, an important social feature of Generation Y, born between the late 1970s and the late 1980s, is their relationship with technology (Bolton et al., 2013).

Feeling comfortable and happy with the presence of technology, Generation Z refers to an age group that prefers social media to socialize (Strauss and Howe, 1991). This generation, which opts to stay in after the increased global terrorist incidents after the 2000s is also called the 'Homeland Generation' (Howe and Strauss, 2000). Generation $\mathrm{Z}$ is also regarded as a generation that often feels inadequate to survive socially without the opportunities offered by the digital world.

In the studies conducted in the field of social sciences, intergenerational differences are emphasized in order to be able to comprehend the changes experienced by societies. People's perception of what is going on in their surroundings and their world views depend on what they experience in the process of socialization. Thus, different generations have their own common cultural identity in community life that separates them from the other generations (Alwin and McCammon, 2003). Unlike the past generations, Generation Z, standing between the real and virtual, makes friends online, interacting with others and spending their free time in this environment. Online games are among the most preferred activities among this generation (Alwin and McCammon, 2003).

\section{Online Games, Violence and Blue Whale Challenge}

In online games, where players play in different venues by interacting, the users (players) share information in a virtual world via internet connection (Ho and $\mathrm{Wu}, 2012)$. For instance, on a web page, specifically Bahamut, which is one gamebased popular community pages in Taiwan, gamers share information and rate computer/video games and online games. Using this platform, games are commented on and popular games are determined (Hsiao et al., 2015). Furthermore, on this web page, online games are classified into different categories, such as role-playing games, action games, shooting games, sports games, adventure games, puzzle games, and war-strategy games ( $\mathrm{Ho}$ and $\mathrm{Wu}$, 2012).

Hoon et al. (2002) classified various online games into four different categories, specifying the characteristics of the games as follows:

- Role playing games: Games in which roles are performed according to a structured scenario.

- Simulation games: Games that enable the user to go through the experience of a simulation with the help of strategic thinking. 
- MUD (Multiuser Dungeons/Dimensions) games: A text-based game or just social space expressed through writing) (Mortensen, 2006).

- Shooting games: Games focused on shooting a target or targets.

Following the studies conducted on computer and console-based video games, there has been an increase in studies conducted on online games. Online games, which include various features such as creating a competitive environment, socializing and challenging, demonstrate the traces of different cultures and reflections of daily life (Hoon et. al., 2002).

Online games have been discussed in the media in recent years. The focus of these discussions is on the fact that online games generally focus on the themes of violence. Families, politicians, and researchers express their concern that such content will increase anti-social behavior (Przybylski et al., 2009). Autonomy and feelings of competence emerge in online games that involve war or organized crime (Przybylski et al., 2009). In these games, players' choice of combat settings, selecting targets, creating strategies, and enforcing personal control over actions reinforce autonomy and competence. In multiplayer games, players running for a common goal share goals and rewards, thus gaining experience in the field of collaboration (Przybylski et al., 2009). In addition to these characteristics, online games are one of the settings where violence is transmitted through media.

Potter (1999) studied the effects of exposure to violence through media content. The presentation of violence in the media content can lead to the emergence of fear along with depersonalization. The content of violence in the media, which draws our attention to its impact on children, is also effective in perpetuating acts of violence.

In 1993, the video game Streetfighter had such a success that surpassed the proceeds of the box-office hit Jurassic Park. Following such an attention-taking success within the entertainment business, Mortal Kombat, distinguished with its content of violence, was also one of the best-selling games in 1993 (Hall, 2011). In the early 1990s, such developments suggested that the content of violence was demanded in the entertainment industry. However, while explaining the relationship of violence with games, it can be suggested that toys (weapons, knives, soldiers, etc.) with the connotation of war have already been included in children's play long before the video games. On examining traditional children's games played on the street long before online games, we found that they differ in many aspects from online games and video games. One difference is the harm given to other people, albeit in a virtual environment. The scenes of violence repeated countless times in online games and video games enable users to harm others to the extent of killing within the game (Goldstein, 1998).

The social changes that online games have created due to the effects of new media technology on community life have been examined with interest. In particular, the negative effects on an individual's mental health have been the subject of a long debate. As a result of the increasingly widespread use of the Internet, there have been increasingly anxious approaches to online games (Williams and Skoric, 2005). Addiction is one of the prominent topics in studies conducted on the psychological effects of online games. Such studies state that 
especially children and young people are more vulnerable to addiction. Attention is drawn to increased social isolation, depression, and anxiety in becoming addicted to online games (Wang et al., 2019). Online games with violent content are also considered to cause aggressive behavior. It is argued that the higher the sense of reality of these violent games, the more aggressively the players behave (Quwaider et al., 2019).

In responses to armed attacks in high schools in the United States in the early 2000s, Anderson and Bushman (2001) stated that the kids who carried out such attacks were young people who made a habit of playing online games with violent content. Anderson and Bushman (2001), who investigated the effects of violence presented in the media in the model they called General Aggression Model (GAM), have underlined that aggressive behavior largely depends on learning, activation, and application of the structures of knowledge stored in memory.

According to the General Aggression Model, learning, rehearsing and activating the cognitive structures related to aggression causes aggressive behavior. One of the most striking examples of violent and aggressive behavior that spread through online games in recent years has resulted from the game called Blue Whale Challenge. However, an important detail to note here is that there is no concrete evidence of the relationship between violence and online gaming. The important problem here, as this study aims to emphasize, is the role of the media in creating negative prejudice against online games. Media content is very effective in creating a panic atmosphere about online games.

The media can be both the source and the provocative agent of the debates in social life. The way a social issue is communicated through the media can lead to intense emotional reactions and consequences that can be referred to as so-called 'media panic'. In this panic atmosphere, negative aspects are often highlighted. Through the media, moral values are also included especially in discussions involving children and young people. In discussions in such a panic atmosphere where different parties take part, following the beginning part, there appears a section where the discussion is intensified and a conclusion part which indicates the solution (Drotner, 1999). A panic atmosphere begins to emerge as a result of the media's making news out of an issue that is perceived as 'threat' by the society. While an unusual event communicates through the language used by the media, an atmosphere begins to form in such a way that seizes the imagination of people (Welch et al., 2002).

Blue Whale Challenge, which takes its name from the suicidal life of whales that have been known to beach themselves, is a suicide game launched in Russia in 2013. In this game, which involves a series of tasks that must be completed in 50 days, the players are being dragged into an increasingly dangerous and lifethreatening situation. Once the players start the game, they are no longer allowed to leave the game and they perform the tasks under the control of the game masters. The players who take commands such as "Watch a scary movie, listen to music in a disturbing way, try to cut one's arm or leg, cut a whale figure into your arm" try to complete 50 steps, respectively (Adeane, 2019).

Players who receive the commands in the game through social media are selected by the game masters. In the game where there are no applications and the 
messages come from networks such as Whatsapp, Facebook, or Snapchat (Mukhra et al., 2017). Every action of the smart phones is monitored in detail through the link sent to the chosen person. This connection, such as a virus, is a serious threat to personal data by following the user's browsing history, email accounts, passwords, phone book, photos, and videos (Mukhra et al., 2017).

Blue Whale Challenge posed a serious threat online, encouraging its victims to various actions such as watching a scary movie at midnight or self-injury with sharp objects (Mukhra et al., 2017). It appears that online games contain content that tend to encourage harm to others. In the Blue Whale Challenge, however, players are directly encouraged to harm themselves

\section{Methodology}

In this study, hypotheses were formed within the framework of research questions. First of all, the basic research question (rq1) of this study is: 'Do the media messages have an effect on the development of a Defensive-Protective, critical or awareness-raising attitudes in Generation $\mathrm{Z}$ towards their position against online games?' Following this basic question, another research question (rq2) is as follows: 'Are online games (Blue Whale Challenge) the only reason for the suicide of young people? Finally, the last question ( $\mathrm{rq3}$ ) is: 'Do social differences have any effect on the interpretation of violence in the media content?'

The following hypotheses have been argued in this study in which the media content in different societies have been examined involving those news reports about the young people who committed suicide by harming themselves as a result of playing the game called Blue Whale Challenge:

h1: Some social realities as well as violence in the media content cause incidents of suicide in Generation Z.

h2: Different societies perceive violence in the media content in line with their own reality.

h3: Media content is effective in establishing the social perspective in line with Defensive-Protective, Critical, Awareness-Raising approaches.

Using the content analysis method, this study analyzed the news about young people who committed suicide by playing the game called Blue Whale Challenge in different parts of the world (e.g. Ukraine, India, the UK). While selecting these countries, the countries where suicide cases related to the Blue Whale game were experienced were searched through web search engine and the selections were made according to the news in the first countries at the time of the study. Also, this study aimed to analyze the relationship between the way the event is communicated through the media and social conditions. Additionally, another issue studied is the effect of the language used by the media on the formation of prejudices towards the game. The content descriptors of the Entertainment Software Rating Board (ESRB) were used for content analysis of news articles.

ESRB was founded in 1994 as a non-profit organization by the US Entertainment Software Foundation ESA. ESRB, which creates advertising 
guidelines and online privacy policies, also rates computer and video games. The aim of the organization is to inform and raise awareness in families about games and at the same time, to make the computer games sector accountable. ESRB carries out the rating in question as a result of the studies conducted with child development experts, academics, and parents. ESRB performs a classification process while rating. While symbols can be used in this classification, there are also evaluations performed under certain categories which are defined as "content descriptors" (Gürcan et al., 2008).

ESRB has been rating video games through rating symbols and content descriptors based on age groups so that game manufacturers can learn about consumer options. Content submitted to the ESRB by game manufacturers is independently rated by the evaluators (Haninger and Thompson, 2004). These content descriptors provide a more specific (e.g., age-based) ranking by explaining the game in detail. Through these content descriptors, game reviewers can evaluate whether the game is eligible. The ESRB also states that, apart from this assessment, it is also possible to achieve coding by making use of a more comprehensive listing for a particular game (Tocci, 2008). In this study, some selected content descriptors of ESRB and their explanations are stated as follows (ESRB, 2019):

Violence: Scenes involving aggressive conflict, bloodless fighting scenes.

Mild violence: Violent scenes with low intensity.

Intense violence: Realistic-looking depictions of death and scenes involving physical conflict.

Profanity: Use of profanity and vulgar language, obscene acts.

Among these content descriptors, the descriptors (violence, mild violence, intense violence, profanity) selected in accordance with the subject and scope of the study were identified as category criteria in the analysis of selected news articles.

Content analysis, which is frequently used in mass communication research, is used in the analysis of written, oral and visual documents. With this method, key themes are identified from the categorized and coded documents depending on the content (Wilson, 2011). The aim of this method is to analyze the trends reflected in the content examined. The news articles examined in the study were about suicide cases and determined by taking into account different countries.

In addition to the content descriptors of the ESRB, the language codes were also determined under the categories of Defensive-Protective and Critical and Awareness-Raising, which were classified under a specific group according to the content of the news articles. These codes were examined separately in each news article. Additionally, this study aimed to identify more clearly the incident-related approaches of the society in which the specific incidences occurred, through the categories and language codes under this group in consideration of the relationship between the two categorical criteria.

The coding units were identified under the analysis categories that convey the dimensions of interest in the content of the news. In the qualitative content analysis conducted within the scope of this research, it was aimed to determine the frequency of appearance and recurrence of the language codes under the specified 
categories in the news articles. The first categorical criteria and the language codes to be used in content analysis of news articles are given in Table 1.

Table 1. Category Criteria of ESRB and Language Codes in News Articles

\begin{tabular}{|l|c|}
\hline Category Criteria & Language Codes in News Articles \\
\hline Violence & Victim-deadly-terrible-tragedy-destructive \\
\hline Mild violence & $\mathrm{n} / \mathrm{a}$ \\
\hline Intense violence & Suicide-hang yourself-cut-toxic pill-drown in \\
\hline Profanity & $\mathrm{n} / \mathrm{a}$ \\
\hline
\end{tabular}

In the second part of the study, the language codes under different categories were determined in order to analyze the social approach towards the phenomena in the societies where the incidents subject to the news took place. The language codes in these categories and news articles are presented in Table 2.

Table 2. Category Criteria of Social Approach and Language Codes in News Articles

\begin{tabular}{|l|c|}
\hline Category Criteria & Language Codes in News Articles \\
\hline Defensive-Protective & $\begin{array}{c}\text { Detention-Police-Crime-Control-Ban-Sin-Blocking- } \\
\text { Censoring }\end{array}$ \\
\hline Critical & Questioning-Addiction-Suspect-Bad Intention \\
\hline Awareness-Raising & Awareness-Alert-Monitoring and Observation \\
\hline
\end{tabular}

The categories that explain the social point of view can be explained as follows:

Defensive-Protective: An approach towards isolation from harmful and aggressive content (Livingstone et al., 2005).

Critical: An approach towards analyzing, interpreting and criticizing how meanings are formed (Kellner and Share, 2005).

Awareness-Raising: An approach to taking measures or improving by analyzing positive and negative aspects.

While defining the criteria of this category, the literature on media literacy was reviewed as supporting data. The relevant news articles have revealed that the categories expressing the social approach somehow indicate the point of view towards the media content. Language codes under these 3 categories seem to prove the approach adopted in the creation of the media content.

According to this, the sources, titles and dates of the news selected from 3 different countries for analyses are as follows:

- Ukraine, Metro.co.uk-Metro Newspaper, "Girl 12, becomes youngest victim of Blue Whale "suicide game", 1 March 2018.

- India, The Indian Express, "Blue Whale Challenge? Girl commits suicide, 'cut here to exit' found written on her hand", 6 December 2018.

- UK, Daily Star, "Was young footballer's death one of 130 linked to 'Blue Whale' social media game?", 24 January 2018. 


\section{Results}

\section{Ukraine, "Girl 12, Becomes Youngest Victim of Blue Whale 'Suicide Game"}

According to the report dated 1 March 2018, a young girl named Anastasia Kysluk committed suicide by hanging herself. Laying emphasis on the game and calling it a 'Suicide Game', the report mentioned that she was the 'youngest victim of the game', and repeatedly stated that her mother was in Poland to work. It was emphasized that Anastasia, who lived with her grandparents, was a successful student based on the statements made by her teachers and classmates.

In the language codes complying with the categorical criteria of ESRB used in the news, the concepts of 'victim-lethal-scary-tragedy-suicide-suicide by hanging' are included under the category of violence. Anastasia, who was very successful in her classes, was described as a victim of the Blue Whale Challenge game.

Ranked among the top 10 countries, Ukraine has a quite high rate of suicide attempts. In recent years, the effect of social media and use of internet on suicide cases has been argued in Ukraine, where it has been asserted that suicide is promoted through these channels. The fact that one hundred children committed suicide in Ukraine in 2015 has drawn attention to the increase in suicide rates in children. Authorities hold the 'death groups' in social networks such as VKontakte, Facebook, Instagram, and Twitter responsible for the deaths. It was also identified that there were approximately 1000 death groups across social networks in December 2017. It was stated that young people aged 13-17 who committed suicide were vulnerable to the negative effects of social networks and had problems in communicating with others (Yaremko and Banakh, 2018). In this report, the vulnerability of the child who committed suicide was emphasized.

Among the categories for social perspective, the concepts of 'custody-crimepolice', which are among the language codes under the category of DefensiveProtective, have been used in the news article. These language codes refer to a protectionist approach involving the police protection of a child, who is shown as a victim, the investigation of the incident, and the detention of the suspects.

After the collapse of communism in 1991, the economic transformations in Russia had an extremely negative impact on the welfare of the population. The transition process in the countries, including Ukraine, caused the economic problems to be felt more intensely. These problems led to social psychological problems in life satisfaction and quality of life in these societies (Abbott and Sapsford, 2006). Another emphasis in the news article analyzed in this study is that Anastasia's mother was in Poland to work and provide her with a better life, while Anastasia had to live with her grandparents away from her mother. The language codes referring to economic insufficiency and the victim being defenseless reveal that the news article was created from a defensive-protectionist perspective. 


\section{India, The Indian Express, "Blue Whale Challenge? Girl Commits Suicide, 'Cut Here to Exit' Found Written on her Hand"}

The news article about a suicide case in India first gave information about the game, stating that a 17-year-old girl, whose name was hidden, committed suicide by hanging herself and wrote the phrase 'cut here to exit', inscribed on her hand with the help of a cutting tool. In the news article about suicide of the girl who liked to play mobile games, the language codes referring to concepts of cuttingcommitting suicide under the intense violence category were frequently used. Under the category of critical content, language codes referring to dependency and suspicion are also attention-taking in the content of the news article.

The incident in Nagpur in Maharashtra State, India's third largest city after Mumbai and Pune, could be interpreted according to the results of research on the impact of new technologies on young people in India (Pathak-Shelat and DeShano, 2014). The youth living in small towns and rural areas in India are still influenced by traditional social structures that shape their individual orientation. Apart from such a community with strong personal ties, the situation of young people living in larger cities is quite different. India's young population under the age of 25 constitutes almost $10 \%$ of the world population. India is also a country with deep and large structural divisions. It can be assumed that factors such as class, caste, gender, geographic location also affect the extent to which young people use the Internet. Internet experience of educated middle class students living in urban areas is quite different from those living in other regions (PathakShelat and DeShano, 2014). Since the news report underlined that the father of the young girl who committed suicide in Nagpur was a retired air force personnel, it can be considered as an example emphasizing the importance of economic discrepancies mentioned here. Her father's profession carried her to a superior economic class different from other young people. The fact that she was described as the child of an urban, middle class family in an economic sense distances her from the traditional structure in which young people in rural areas usually live. Additionally, the fact that she lived in the city with a better economic status compared to those living in the countryside caused her to be described as one of the young people living in cities and becoming lonely.

Another detail that draws attention in the news article is the emphasis on the academic failure of the young girl who committed suicide. As her college applications failed to be accepted, her father stated that she was unsuccessful. The news report mentioned her addiction to online games with a critical language. Therefore, the relationship between the suicide and online games should be reevaluated here. As emphasized in this study, there is no concrete evidence that online games directly cause suicide. As seen in this example, a variety of factors such as familial and psychological reasons appear to be influential on the suicide of the young girl.

In India, which attracts attention with its density in the young population between the ages of 15-30, it is stated that when the energy of this young population is not utilized sufficiently and efficiently, the acts of aggression and 
violence among youth increase (Tripathi, 2017). These violent actions include mocking, lying, encouraging coercive behavior, and repeated vulgarity. There is a significant gap in the country's legislation relevant to such issues. It is emphasized that legal arrangements should be made in addition to developing the technological infrastructure that is necessary for the prevention of violent acts that are experienced on the Internet (Tripathi, 2017).

Moreover, the critical perspective draws attention in the news article reporting a 17-year-old girl who is thought to have committed suicide under the influence of the Blue Whale Challenge in India. The girl's family referred to the games she had played on the internet as the cause of her suicide. The fact that the young girl was addicted to online games and had low academic success supports this critical point of view, but also shows that the relationship between online games and suicide should be evaluated together taking different factors into consideration as well.

\section{UK, Daily Star, "Was Young Footballer's Death One of 130 Linked to 'Blue Whale' Social Media Game?"}

Daily Star in the UK reported that a 15-year-old football team player, Jordan Moseley, committed suicide by hanging himself in his bedroom, adding that other young people were also claimed to have committed suicide before at different dates, because of online games. An important detail in the news article arises with the language codes used. For example, Blue Whale Challenge was defined as 'social network craze, experiment', and only the language code of 'bad faith' was found under the critical content category. Jordan's original cause of death was claimed to be an accident, considering that it would not be possible for a young and successful athlete to have committed suicide with everything he could have in his life. Here again, the game Blue Whale Challenge was presented as the only responsible factor. Such a perspective, however, ignores the fact that the boy who committed suicide may also have been affected by different factors as a member of a society.

The use of mobile phones is intense in the young population who use them to communicate through social media networks. It is clear that the Internet plays a significant role in the social and emotional development of the youth. Today, even parents now prefer to use technology to communicate with their children. On the other hand, socialization-communication, access to sound information and access to advanced learning opportunities are listed as the positive aspects of the Internet (O'Keeffe and Clarke-Pearson, 2011). Jordan's father said in his statement that there was correspondence with friends in his son's mobile phone, as usual, and that he did not encounter anything strange or unusual, which can be considered as an important detail in creating the perspective towards the incident.

The Report of Byron (2008), evaluates how children and young people are affected by social media and electronic media with respect to different age groups. In this report, it is stated that young people between the ages of 15 and 18, are still under the responsibility of their families. According to the report, young people in this age group want to have different experiences while they are under the responsibility of their families. Alcohol use or sexual experiences are desired 
especially during this period. Young people are particularly affected by the content they see in mass media. In a like manner, the news about Jordan reported that a responsible young person who had won the trust of his family lost his life in an experiment.

\section{Conclusions}

Based on the hypotheses of this study, Defensive-Protective, Critical, and Awareness-Raising approaches were observed in different dimensions in each of the news articles collected from the three different countries. When the news article about the incident in Ukraine is examined by taking h1 (h1: Some social realities as well as violence in the media content cause incidents of suicide in Generation Z) into consideration, it is clearly seen that the country has a social segment that suffered economic problems. In addition, the effect of this reality in suicide cases, which is common among young people in the country, is also indicated. In Ukraine, it is observed that there is a Defensive-Protective approach as a social perspective reflected in the news article. The effect of social realities can be observed in the approach to the events as stated in h2 (h2: Different societies perceive the violence in the media content in line with their own reality). The manner in which the text of the news has been created as mentioned in h3 (h3: Media content is effective in establishing the social perspective in line with Defensive-Protective, Critical as well as Awareness-Raising approaches), also has an effect on the adoption of such a protective approach. The news includes the language codes referring to the negative effects of the Internet and what a successful young girl went through.

Within the context of the social realities mentioned in h1, the news article about the incidence in India covers that there is a gap in the legal system which is underregulated in parallel with technological developments in the country. There are examples for the specific expressions of the different social realities conveyed in $\mathrm{h} 2$ through the language codes in which intense violence was clearly expressed. In addition, it can also be observed that the relevant language codes were used for a Critical approach in the construction of the news article.

The news story about the incident in England was constructed quite differently from those in the other three countries. Blue Whale Challenge, defined as 'social network craze', reflected a different social structure besides the conservative, protective, and stimulating approaches of the other three countries. Thus, the hypotheses $\mathrm{h} 1$ and $\mathrm{h} 2$ revealed a different reality in the case of England. An examination of the manner in which the news was created reveals the striking language codes used for the heroic death of a young person as a successful student and athlete who lost his life as a result of an accident while trying to conduct an experiment.

When the news articles are analyzed together with the assumptions put forward by this study, it is concluded that there are changes in the ways an online game is claimed to cause suicide of young people in societies with different living conditions, due to social differences. In more comprehensive studies on the 
subject, it will be useful to conduct a study to evaluate the structural origins of news sources and the comments of readers. The discussion of the subject within the framework of conservative-critical perspectives on media literacy will be an important step for the literature.

This study aimed to examine the structure of the media and online games that trigger violence as well as the role of media in reflecting people's overall perspective. In this context, the news articles constructed within the framework of different social realities were examined by content analysis method by taking examples from different countries of diverse geographies, including Ukraine, India and the UK in accordance with the categories of Defensive-Protective and Critical, Awareness-Raising.

As a result of this review, detailed evaluations have been made under Results and Discussion. However, if an evaluation is to be made according to the research questions and hypotheses determined in the study, the following conclusions will be reached:

- Media content has a profound impact on the way society views things. This impact sometimes even results in the emergence of a panic atmosphere.

- It is not right to come to a conclusion based on the assumption that online games alone lead to suicide.

- Some social conditions should also be considered as reasons leading to suicide.

- Just like the impact of social conditions on the process of creating media messages, social reactions are affected by media messages in a similar manner.

\section{References}

Abbott, P., Sapsford, R. (2006). Life-satisfaction in post-Soviet Russia and Ukraine. Journal of Happiness Studies, 7(2), 251-287.

Adeane, A. (2019). Blue Whale: what is the truth behind an online 'suicide challenge'? BBC Trending.

Alwin, D. F. (2002). Generations x, y and z: Are they changing America? Contexts, 1(4), $42-51$.

Alwin, D. F., McCammon, R. J. (2003). Generations, cohorts, and social change. In Handbook of the Life Course, 23-49. Boston: Springer.

Anderson, C. A., Bushman, B. J. (2001). Effects of violent video games on aggressive behavior, aggressive cognition, aggressive affect, physiological arousal, and prosocial behavior: a meta-analytic review of the scientific literature. Psychological Science, 12(5), 353-359.

Bolton, R. N., Parasuraman, A., Hoefnagels, A., Migchels, N., Kabadayi, S., Gruber, T., et al. (2013). Understanding Generation $Y$ and their use of social media: a review and research agenda. Journal of Service Management, 24(3), 245-267.

Byron, T. (2008). Safer children in a digital world: the report of the Byron Review. Nottingham: DCSF Publications.

Daily Star (2018). Was young footballer's death one of 130 linked to 'Blue Whale' social media game? Daily Star. 
Drotner, K. (1999). Dangerous media? Panic discourses and dilemmas of modernity. Paedagogica Historica, 35(3), 593-619.

Entertainment Software Rating Board - ESRB (2019). Rating categories, content descriptive. ESRB.

Goldstein, J. (1998). Why we watch: the attractions of violent entertainment. NY: Oxford University Press.

Gürcan, A., Özhan, S., Uslu, R. (2008). Digital games and their effects on children. Ankara: Prime Ministry Family and Social Research General Directorate.

Hall, S. (2011). You've seen the movie, now play the game: Recoding the cinematic in digital media and virtual culture. Doctoral Dissertation. Ohio: Bowling Green State University.

Haninger, K., Thompson, K. M. (2004). Content and ratings of teen-rated video games. Jama, 291(7), 856-865.

Ho, C. H., Wu, T. Y. (2012). Factors affecting intent to purchase virtual goods in online games. International Journal of Electronic Business Management, 10(3), 204-212.

Hoon, K., Park, J. Y., Yul, K. D., Moon, H. L., Chun, H. C. (2002). E-lifestyle and motives to use online games. Irish Marketing Review, 15(2), 71-72.

Howe, N., Strauss W. (2000). Millennials rising the next great generation. New York: Vintage Books.

Hsiao, K. L., Lin, J. C., Wang, X. Y., Lu, H. P., Yu, H. (2015). Antecedents and consequences of trust in online product recommendations: an empirical study in social shopping. In A Focus on Consumer Behaviors and Experiences in an Online Shopping Environment, 77-99. UK: Emerald.

Huang, Y. C., Petrick, J. F. (2010). Generation Y's travel behaviors: a comparison with Baby Boomers and Generation X. Tourism and Generation Y, 1(Dec), 27-37.

Jorgensen, B. (2003). Baby Boomers, Generation X and Generation Y? Policy implications for defense forces in the modern era. Foresight, 5(4), 41-49.

Katz, S. (2017). Generation X: a critical sociological perspective. Generations Journal of the American Society in Aging, 41(3), 12-19.

Kellner, D., Share, J. (2005). Toward critical media literacy: core concepts, debates, organizations, and policy. Discourse: Studies in the Cultural Politics of Education, 26(3), 369-386.

Lindsay, J., Dill -Shackleford, K. E., Anderson, K. B., Bartholow, B. (2014). The proliferation of media violence and its economic underpinnings. In E. Douglas Gentile (ed.), Media Violence and Children, 1-44. US: Praeger.

Livingstone, S., Van Couvering, E., Thumim, N. (2005). Adult media literacy: a review of the research literature. London: Department of Media and Communications, London School of Economics and Political Science.

Metro.co.uk-Metro Newspaper (2018). Girl, 12, becomes youngest victim of Blue Whale 'suicide game'. Metro.co.uk-Metro Newspaper.

Mortensen, T. E. (2006). WoW is the new MUD: social gaming from text to video. Games and Culture, 1(4), 397-413.

Mukhra, R., Baryah, N., Krishan, K., Kanchan, T. (2017). 'Blue Whale challenge': a game or crime? Science and Engineering Ethics, 25(1): 285-291.

Nilsen, A. (2014). Cohort and generation: concepts in studies of social change from a life course perspective. Families, Relationships and Societies, 3(3), 475-479.

O'Keeffe, G. S., Clarke-Pearson, K. (2011). The impact of social media on children, adolescents, and families. Pediatrics, 127(4), 800-804.

Pathak-Shelat, M., DeShano, C. (2014). Digital youth cultures in small town and rural Gujarat, India. New Media \& Society, 16(6), 983-1001.

Potter, W. J. (1999). On media violence. UK: SAGE Publications. 
Przybylski, A. K., Ryan, R. M., Rigby, C. S. (2009). The motivating role of violence in video games. Personality and Social Psychology Bulletin, 35(2), 243-259.

Quwaider, M., Alabed, A., Duwairi, R. (2019). The impact of video games on the players behaviors: a survey. Procedia Computer Science, 151(2019), 575-582.

Sandeen, C. (2008). Boomers, Xers, and Millennials: who are they and what do they really want from continuing higher education? Continuing Higher Education Review, 72(Fall), 11-31.

Strauss, W., Howe, N. (1991). Generations: the history of America's future. New York, NY: William Morrow.

The Indian Express (2018). Blue Whale Challenge? Girl commits suicide, 'cut here to exit' found written on her hand. The Indian Express.

Tocci, J. (2008). Seeking truth in video game ratings: Content considerations for media regulation. International Journal of Communication, 2(26), 561-586.

Tripathi, V. (2017). Youth violence and social media. Journal of Social Sciences, 52(1-3), $1-7$.

Wang, H. Z., Sheng, J. R., Wang, J. L. (2019). The association between mobile game addiction and depression, social anxiety, and loneliness. Frontiers in Public Health, 7(Sep), 247.

Welch, M., Price, E. A., Yankey, N. (2002). Moral panic over youth violence: wilding and the manufacture of menace in the media. Youth \& Society, 34(1), 3-30.

Williams, D., \& Skoric, M. (2005). Internet fantasy violence: a test of aggression in an online game. Communication Monographs, 72(2), 217-233.

Wilson, V. (2011). Research methods: content analysis. In Evidence Based Library and Information Practice, 177-179.

Yang, Y. (2008). Social inequalities in happiness in the United States, 1972 to 2004: an age period-cohort analysis. American Sociological Review, 73(2), 204-226.

Yaremko, O., Banakh, S. (2018). Incitement to suicide with social networks and the internet: problems of criminal liability in Ukraine. In ACIT 2018, June 1-3, Czech Republic, 271-274. 



\title{
"This Virus is a Common Threat to All Humans": Discourse Representation of COVID-19 in Selected Newspaper Editorials
}

\begin{abstract}
By Ayo Osisanwo*
Existing studies on viruses with bias for COVID-19 have mainly been carried out from non-linguistic fields. Linguistics-related studies have not examined the media representation of COVID-19 since it is a recent development. This study, therefore, identifies the representational strategies, discourse structures and discourse strategies deployed by selected newspapers in representing COVID19 and associated participants. Data were retrieved from selected COVID-19related editorials from four purposively selected countries and continents across the world: New York Times (USA, North America), The Guardian (UK, Europe), China Daily (China, Asia) and The Punch (Nigeria, Africa), published in the early periods of the pandemic, and precisely from January 1- March 31, 2020. Guided by aspects of van Dijk's socio-cognitive model of critical discourse analysis on ideological discourse structures, data were quantitatively and qualitatively analysed. The newspaper editorials unusually converged to negatively represent an issue - COVID-19 - because it is largely negatively viewed by all. Ten representational strategies (like economic cankerworm, threat to humans, common enemy), six discourse strategies (like demonising, criminalising, condemnation) and twelve ideological discourse structures (like Actor Description, Authority, Burden) and different participant representations and roles (like solver, potential super spreader) were identified in the study. The newspapers largely set the agenda on the negative representation of the virus and its potential havoc on all facets of human endeavours, thereby giving emotional and informational appeal to all to join hands in earnestly silencing the epidemic.
\end{abstract}

Keywords: COVID-19, media representation, newspaper editorials, discourse strategies, discourse structures

\section{Introduction}

The novel coronavirus (otherwise known as COVID-19), which is an acute respiratory disease, allegedly evolved in Wuhan China in December 2019. The first official report of the virus was made on December 8, 2019. The virus has rapidly spread from a single city of Wuhan to other parts of China within a short time and has since become a global pandemic. This has not only attracted attention all over the world, but has equally hampered a lot of activities all over the world. In fact, the World Health Organization (WHO), on 30 January 2020, officially declared the COVID-19 epidemic as a public health emergency of international concern. As at 12noon on April 19, 2020 the number of recorded cases of COVID-

\footnotetext{
*Lecturer, University of Ibadan, Nigeria.
} 
19 had risen to 2,347,777; the number of deaths was put at 161,126; the number of recovered and discharged cases was 605,661; while 1,580,990 were the outstanding active cases (worldometres.info/coronavirus). The WHO (2020) has described coronavirus (COVID-19) as an infectious disease caused by a newly discovered novel coronavirus, and most people infected with the COVID-19 virus often experience mild to moderate respiratory illness and recover without requiring special treatment. Meanwhile, older people, and those with underlying medical problems like cardiovascular disease, diabetes, chronic respiratory disease, and cancer are more likely to develop serious illness. The WHO warned that the best way to prevent and slow down its transmission is for all to be well-informed about the COVID-19 virus, the disease it causes and how it spreads ${ }^{1}$. The WHO has further confirmed that the COVID-19 virus spreads primarily through droplets of saliva or discharge from the nose when an infected person coughs or sneezes; and further advised that since there is no known vaccines or treatments for COVID-19 yet, human beings across the world must practise respiratory etiquette (for example, by coughing into a flexed elbow or tissue).

Compared with other illnesses such as influenza, SARS, Ebola and so forth, COVID-19 has been presumed as (one of) the major killer-diseases across the world in 2020. COVID-19 is a major, if not the most, cause of human mortality in 2020. Arguably, it has had the highest fatality rate among known viruses in 2020. Different ailing conditions have had encounters with the human race at different times. A hundred and two years ago, that is, in the year 1918, there was the influenza pandemic that ravaged the globe. Potter (2001) reports that 50 percent of the world's population was infected during the 1918 pandemic, while the total mortality was between 40 and 50 million out of a world population of 1.8 billion then (Barry, 2005). Hence, the fatality rate was 5.6 percent. Similarly, seventeen years ago, that is, in the year 2003, there was the outbreak of severe acute respiratory syndrome (SARS). According to the WHO, 8098 people worldwide contracted SARS during the 2003 outbreak, out of which 774 died, making the SARS fatality rate 9.6 percent. Comparing the two, the WHO remarked that the death toll percentage of 9.6 percent from SARS was far higher than that of the 5.6 percent of the 1918 influenza pandemic. With the data supplied earlier, the fatality rate of the current COVID-19 has reached almost seven percent.

The Economist on April 7 confirmed the deadly nature of the coronavirus thus: "The novel coronavirus has killed tens of thousands of people around the world since it first emerged in China last December.... It is a choice between life, death and economy!"2 No doubt, the level of fear in the world has been documented by the London Economist, as there is palpitation in the world with the current COVID-19 outbreak. Already, it is the first severe infectious disease that emerged and attracted so many victims within a very short time in the 21 st Century.

COVID-19 is a very sensitive matter; its sensitivity and outbreak has made it a foremost matter and most reported issue in all tabloids across the world in 2020. The attention given to COVID-19 has suppressed some other events happening concurrently more so that the world seems to have been in a standstill combatting

\footnotetext{
${ }^{1}$ https://www.who.int/health-topics/coronavirus\#tab=tab_1.

${ }^{2}$ https://www.economist.com/topics/london-1
} 
the coronavirus. Media constitute one of the main means through which text consumers get to know more about coronavirus and its escapades. Hence, news producers sit at a vantage position of orienting the readers. No doubt, media outlets have equally risen up to the occasion to give the virus a wide publicity and reportage across the world. Hence, COVID-19 has been the subject of continuous widespread media coverage, especially since the beginning of 2020 .

Existing works on media discourse have focused on how selected persons, groups or issues are represented based on their religious, social or political inclinations, while others have been based on their tribal proclivity or ideological stance (Majid, 2008; Mahdi, 2009; Talaat, 2011; Osisanwo, 2011, 2016a, 2016b, 2017a, 2017b, 2019; Oyeleye and Osisanwo, 2013a, 2013b; Chiluwa and Odebunmi, 2016; Osisanwo and Oluwayemi, 2018). Such studies have examined how the media have represented actors and their actions in these events. However, the newness of coronavirus which generated an uproar and alarm across the globe has denied it consideration in the academia. Some of the existing works on COVID-19 are works from the sciences. The science-related studies have explored the epidemiology, causes, clinical manifestation, diagnosis, prevention and control of the novel coronavirus. However, studies exploring the linguistic intervention have not emerged. Studies in this domain, like the current one, are urgently needed to contribute their linguistic and discourse interventions to combatting the outbreak of COVID-19. Linguists have not examined COVID-19 in relation to rhetoric, media representation and so forth. Meanwhile, existing linguistic studies (e.g., Eagleton, 2004; Washer, 2004; Chen, 2005; Larson et al., 2005; Wallis and Neriich, 2005; Baehr, 2006; Chiang and Duann, 2007; Trčková, 2015) or virusrelated studies have only considered the representation of related aliments like Influenza, SARS, Ebola. This paper therefore focuses on the discourse representation of coronavirus in the contents of the editorials of major newspapers selected across four countries from four continents across the world. What sort of representations have the newspapers used to form the readers' opinions on coronavirus?

\section{Theoretic Orientation}

Critical Discourse Analysis (CDA) is the study of opaque relationships of causality and determination between discursive practices, events and texts, and wider social and cultural structures, relations and processes (Fairclough 1995; Wodak 2002). CDA is a special form of social cognition shared by social groups which forms the basis of their social representations and practices including their discourse (van Dijk, 2001a). The socio-cognitive approach to CDA links language practice to social cognition. This approach focuses on the fundamental importance of intuition and society in critical analysis of discourse. The socio-cognitive approach of van Dijk incorporates what van Dijk calls mental models. A mental model is a subjective representation of specific events covered in discourse and it represents the personal Episodic Memory of individuals because it can be identified with people's experience (van Dijk 2001a, 2006a). Though mental models are personal, they also "involve the instantiation of general, socially shared 
knowledge or beliefs" (van Dijk, 2006b, p. 367), and signify the necessary interface between the personal and the social, between discourse and society. The mental models describe and explain "how social structures influence and are affected by discourse structures" (van Dijk, 2001b, p. 112). Discourse and social structure are mediated by social cognition. In essence, the human mind is a very significant dimension in the socio-cognitive approach. The capability of the socio-cognitive model of CDA to account for the diverse nature of the language use in media representations favours it for this study. To understand media discourse, there is need to examine the underlying media cognition of the represented participants in news reports and editorials. Such discourse is not only social in orientation but also embodies individual and non-individual characters who are assigned different roles in the representations.

Out of the hundreds of possible categories, van Dijk (2006c, pp. 735-739) introduces 27 categories of ideological discourse structures which include actor description, authority, burden (Topos), categorisation, comparison, consensus, counterfactuals, disclaimer, euphemism, evidentiality, example/illustration, generalisation, hyperbole, implication, irony, lexicalisation, metaphor, selfglorification, norm expression, number game, polarisation, Us-Them, populism, presupposition, vagueness, victimisation, dramatisation and polarisation. According to van Dijk the ideological discourse often features the following overall strategies of what might be called the ideological square: emphasise our good things, emphasise their bad things, de-emphasise our bad things, de-emphasise their good things. However, the manners in which such ideologies are "expressed and especially persuasively conveyed may of course also involve many formal aspects of grammar, discourse and conversation". Meanwhile, we have found twelve of the twenty-seven useful for the purpose of this paper. They include Actor description, which has to do with the way in which actors or members of a particular society are described either in a negative or positive way; Authority, which has to do with mentioning authorities to support one's case; Burden, which has to do with the use of standard argument as sufficient reasons to accept the conclusion; comparison, which has to do with comparing ingroups and outgroups; evidentiality, which involves the use of some evidence or proof to support one's knowledge or opinion; Example/Illustration, which involves using concrete examples in form of short stories to illustrate or make a general point more credible; generalisation, which has to do with using generalisations instead of giving concrete stories; lexicalisation, which involves using specific lexical items to express underlying concepts and beliefs; metaphor, which is the use of imaginative and powerful words and expressions to describe; negative otherpresentation, which involves classifying outgroups as bad; norm expression, which involves giving norm statement about what "we" should and should not do; Number game, which has to do with the use of numbers and statistics to appear credible. Therefore, the identified twelve ideological discourse structures of the socio-cognitive approach will be applied to this study because they are capable of accounting for implicit information that forms writers' mental models. The related aspects of this socio-cognitive model are represented on Figure 1. 
Figure 1. Media Representation of COVID-19






\section{Methods}

For data, editorials on coronavirus from four purposively selected newspapers from four countries and four continents across the world were purposively selected. The selected newspapers are papers rated within the top 200 newspapers in the world (4imn.com Newspaper Web Ranking). They include New York Times (USA, North America), The Guardian (UK, Europe), China Daily (China, Asia) and The Punch (Nigeria, Africa). The selected editorials on coronavirus-related issues are those published in the early periods of the pandemic, and precisely from January 1 - March 31, 2020. The online versions of the papers were assessed. From the 364 newspapers published during the selected period, that is 91 publications per newspaper, the editorials that were strictly written on coronavirus were retrieved thus: New York Times (12 editions), The Guardian (18 editions), China Daily (12 editions) and The Punch (5 editions). The articles were critically read and the aspects that relate to discourse representations of coronavirus were culled out for quantitative and qualitative analyses - with more emphasis on content-anddiscourse.

\section{Analysis and Findings}

As presented on Figure 1, which is the summary of the findings on media representation of COVID-19, ten representations are identified in the sampled newspaper editorials. The representations are COVID-19 as outbreak, pandemic, economic cankerworm, threat to humans, war, killer (disease), plague, common enemy, fire and disaster. In addition, six discourse strategies: demonising the disease, criminalising the disease, calling the state to action, emotional and informational appeal to the masses, condemnation of the state, and historical reference; twelve ideological discourse structures: actor description, authority, burden, comparison, evidentiality, illustration, generalisation, lexicalisation, metaphor, negative other-presentation, norm expression, and number game; and different participant representations and roles: solver, (potential super) spreader, and so forth, were identified in the study. Figure 2 presents the percentage of dominance of the representations. I now discuss the discourse representations and other parts of the analysis.

Figure 2. Discourse Representation of COVID-19 (in Percentages)






\section{Representations}

The newspaper editorials unite to index COVID-19 as a negative phenomenon. Hence, a major representation generated to cut across all representations is the negative portrayal of COVID-19. All the identified ten representations are subsumed under the negative representation of the virus.

\section{Outbreak}

Representation of COVID-19 as outbreak is the most dominant (26\%) representation in our data corpus. The newspaper editorials converge to represent COVID-19 as outbreak - a sudden rise in the incidence of a disease. The reason for the convergent representation is not far-fetched since COVID-19 or coronavirus has been largely described as a condition that has brought about a sudden increase in the number of carriers across the world. Texts 1 to 3 exemplify the deployment.

(1) Lombardy, a sophisticated region in the north with a good health care system, was quickly overwhelmed by its coronavirus outbreak (NYT, March 12, 2020).

(2) Data shows that the UK's coronavirus outbreak is following a similar trajectory to Italy's, with around a two-week delay (The Guardian, March 22, 2020).

(3) In the wake of the outbreak of the virus in China, the country received heartwarming support of various kinds from many countries and a number of international and regional organizations, which consolidated the Chinese people's confidence that they would be able to overcome the virus (China Daily, March 30, 2020).

In texts $1-3$, the editorials of the sampled papers deploy such discourse structures as lexicalisation, burden, illustration, evidentiality to support the representation of COVID-19 as an outbreak. The lexicalisation of this representation implicates the virus as an epidemic eruption that necessitates exigent attention. In addition, the premodification of the word "outbreak" in the expression "coronavirus outbreak" underscores possession, and implicates COVID-19 as the agent behind the outbreak. The expression, "outbreak of the virus in China" equally nominalises the outbreak in point as the COVID-19 virus, and further implicates China as the source of the virus. The rendition of the editorial in text 1 deploys Burden to incriminate COVID-19 as a dastardly outbreak which was able to render helpless a region that had sophisticated health care system, that is, Lombardy, Italy. This argument, adduces the Lombardy experience as the need to accept the conclusion that COVID-19 is an epidemic or outbreak, and sufficiently underscores the need for the state in conjunction with the health-workers to immediately collaborate to picket the outbreak before it goes out of control. 


\section{Pandemic}

The newspaper editorials represent COVID-19 as a pandemic - a disease that spreads over a whole country or the whole world. This representation, accounting for $22 \%$ of the total representations is exemplified in texts 4-6.

(4) Scientists from the Johns Hopkins Center for Health Security estimate that the coronavirus pandemic could necessitate anywhere from 200,000 to 2.9 million I.C.U. visits, and ultimately require some 67,000 I.C.U. beds (NYT, March 12, 2020).

(5) It now appears almost inevitable that the new coronavirus outbreak will soon be identified as a global pandemic (The Guardian, March 18, 2020).

(6) FOR Nigeria, which has just recorded its first novel coronavirus death, the tragic footprints of the global pandemic have become inescapable (The Punch, March 24, 2020).

The preponderant use of "pandemic" to describe COVID-19 in the editorials is motivated by the subsisting experience from the disease. The newspapers converge to implicate that the virus is a pandemic, post-modifying the virus in "coronavirus pandemic" (text 4), and nominalising the virus in "a global pandemic" (text 5) and "the global pandemic" (text 6). In text 4, the editor deploys the use of Authority (Argumentation) and Evidentiality, citing Scientists from the Johns Hopkins Center for Health Security and the estimated figures to support his case and authenticate the evil effect of COVID-19 as a pandemic that requires all attention to mitigate the projected negative impact. Both texts 5 and 6 deploy the use of Actor Description to designate coronavirus. The word "pandemic" has to do with a disease that spreads over a whole country, in the first instance, and if not properly managed, could spread globally. The point in The Guardian's editorial in text 5 "the new coronavirus outbreak will soon be identified as a global pandemic" accentuates the growth in the spread of the virus. The representation incriminates the states and world leaders as not doing enough to combat the virus. COVID-19 is further given a negative representation in text 6 "the tragic footprints of the global pandemic have become inescapable". The information of the arrival of the virus in Nigeria and the construction of the inescapability of the footprints of the virus in Nigeria call on the leaders, health-workers and individuals to activate their roles in the different containment measures.

\section{Economic Cankerworm}

A canker(worm), viewed in the strict sense as a disease that destroys the woods of plants and trees, is also generally seen as an evil or dangerous influence that spreads and affects people's behaviour. The newspaper editorials converge to imply that COVID-19 is an economy canker that, if not immediately tackled, will throw the whole world beyond economic recession. The preponderant representation of COVID-19 as an economic canker takes $14 \%$ of the total representations. Texts 7-10 exemplify this representation. 
(7) Mr. Trump already has signed an $\$ 8.3$ billion spending bill focused on public health measures, but more is needed (NYT, March 12, 2020).

(8) "Using the word pandemic now does not fit the facts, but it may certainly cause fear", the WHO director general, Dr Tedros Adhanom Ghebreyesus, warned on Monday. As concern spreads, economic effects are growing alongside the human toll. Stock markets have taken a hammering. Airlines are suffering, major international events are being cancelled, and companies dependent on Chinese-made components have halted production (The Guardian, February 25, 2020).

(9) Since almost all major economies, ranging from the European Union to East Asia, and the United States, are battling the virus, and the infection rate is in an explosive growth stage in many of the countries, a global recession is becoming ever more likely as the virus spreads worldwide (China Daily, March 11, 2020).

(10) AS the country braces for the inevitable adverse economic impact of the raging coronavirus pandemic, the federal and monetary authorities, the legislature and the private sector have separately been rolling out a raft of measures to stave off catastrophe. ........Italy's $€ 3.5$ billion stimulus, France's $€ 45$ billion, Australia's A \$17.6 billion, South Korea's US\$9.8 billion and China's \$270 billion loan relief programmes are designed to provide immediate succour to the sick, maintain infrastructure, keep companies and wages afloat and support consumer spending. Efforts by Nigeria should aggregate these objectives (The Punch, March 31, 2020).

The editorials demonise COVID-19 by portraying the virus as an evil that is capable of throwing the world economy into mayhem. Since the state needs to fund the health facilities with huge sum while a running economy that could have kept running to cushion the depleting effect of the funding is at a standstill, this portends a grave danger to the world. Text 7 deploys Illustration discourse strategy to exemplify the huge amount " $\$ 8.3$ billion spending bill" that the US President has already released to fight the virus. The expression that suggests the insufficiency of the fund "but more is needed" implicates the virus as a canker (worm) that is eating into the fabrics of the world economy. The editor in text 8 also deploys example/illustration discourse strategy, lexicalisation and Negative otherpresentation to implicate the virus as economic cankerworm. The use of expressions such as "Stock markets have taken a hammering", "Airlines are suffering", "major international events are being cancelled", and "companies dependent on Chinese-made components have halted production" to lexicalise and appropriately illustrate how the supposed economy boosters are being grounded underscores the crumbling posture of the economy. Similar strategies are deployed in text 9 , while the editor concludes by pontificating that "a global recession is becoming ever more likely as the virus spreads worldwide", having cited the unprecedented dent the situation has recently had on "all major economies" across the world: "the European Union", "East Asia", and "the United States", all of who are combatting the virus, using all their economic strength with no immediate hope of recouping. Yet, the infection keeps growing and exploding in many other countries. In text 10 , the editorial portrays the virus using "inevitable adverse economic impact of the raging coronavirus pandemic." Hence, the inevitability of 
the portending effect of the economic adversity incriminates COVID-19 as a cankerworm already propelling the world economy into shambles.

\section{Threat to Humans}

The newspapers construct COVID-19 as threat - an expression of intention to inflict evil, injury, or damage - to humans. This representation (with $11 \%$ of the identified representations) is evident in texts 11-12.

(11) What has altered is the nature of the threat. Covid-19 is 50 times more deadly than swine flu. It is far more easily transmitted. The world is more globalised, heightening the risk of rapid spread of the virus, especially one that travels with close contact (The Guardian, March 31, 2020).

(12) Washington should look at what is happening in the US and realise that this is not a time for one-upmanship. Instead of trying to use the pandemic as a means to segregate China from the international community, it should embrace our shared identity as humans in the face of this common threat (China Daily, March 26, 2020).

The newspapers converge to paint COVID-19 as a threat to the existence of man, especially since it is capable of inflicting evil, injury, or damage. In texts 1112 , the editorials of the sampled papers deploy such discourse structures as actor description, lexicalisation, burden illustration, evidentiality and number game, to support the representation of COVID-19 as a threat to humanity. As a case in point, text 11 commences with Actor Description to talk about the nature of COVID-19, described as a threat in "What has altered is the nature of the threat. Covid-19 is 50 times more deadly than swine flu", deploying Number Game, spiced with call to action by the leaders to immediately do the needful to placate the evil virus. The demonisation of the virus as evil and its criminalisation instill the need for caution and vigilance in the mind of the citizenry to either cooperate with the government and health providers and or protect themselves from an impending global threat, since the virus is further given Actor Description as being "far more easily transmitted". The description further cautions travellers and implicates them as potentially more vulnerable thus: "The world is more globalised, heightening the risk of rapid spread of the virus, especially one that travels with close contact".

Text 12 implicates the virus as not just a threat, but a common threat to all humans. It commences by deploying the discourse structure "Burden" thus: "Washington should look at what is happening in the US and realise that this is not a time for one-upmanship" in order to canvass for oneness for humanity to defeat the common threat - the epidemic eruption that requires instant reprisal. China Daily ideologically negatively implicates the US government's show of arrogance and untimely segregation, implying that the US leadership was "trying to use the pandemic as a means to segregate China from the international community" since the COVID-19 had started wreaking havoc on the US. China Daily further deploys Norm Expression to categorically state what it expected of the US at a period like 
this - "it should embrace our shared identity as humans in the face of this common threat", castigating the virus as a common threat to all humanity.

\section{Warfare}

Warfare implies struggle between competing entities or an activity undertaken by a political unit (as a nation) to weaken or destroy another. The newspaper editorials perceive and describe COVID-19 as a war (with 10\% of the identified representations) to be fought, as evident in texts 13-15.

(13) Mr. Trump has proclaimed himself a "war president." Why, then, won't he rally Americans around this cause? Winning this war will require shared sacrifice, and tremendous short-term hardship for Americans. But failure would mean devastating loss of life and prolonged, widespread economic pain (NYT, March 24, 2020).

(14) Britain has finally declared war on Covid-19. Ministers say that the science left them no alternative but to fight. This was never a war of choice. The virus is no ordinary foe (The Guardian, March 17, 2020).

(15) The war against the virus is one we all have to fight together, the longer the pandemic persists the worse its effects will be (China Daily, March 26, 2020).

Texts 13-15 deploy different ideological discourse structures including Authority, Actor Description and Metaphor to represent COVID-19 as war or warfare. The expressions "Winning this war", "war on COVID-19" and "The war against the virus" in texts 13,14 , and 15 respectively, implicates and metaphorically presents COVID-19 as war, stating it is a battle to be fought and won by all. First, text 13 uses Authority to take recourse to the pronouncement of the US president, and uses Actor Description to describe him as a self-acclaimed "war president", capable of leading the war against COVID-19. The unveiled question, "Why, then, won't he rally Americans around this cause?" is a subtle condemnation strategy strategically positioned in the editorial to query the president's lethargy and indecisive pace in prosecuting the war. The last sentence presents the consequential projected effect on Americans should the president continue to delay in swinging to action. Similarly, text 14 subtly attacks the lateness of the leadership of Britain in going to war against COVID-19 as suggested by the word "finally". The text equally underscores the compulsion of the war, "This was never a war of choice". Text 15 advocates oneness in the battle "we all have to fight together," and expounds the need for urgency in the war thus: "the longer the pandemic persists the worse its effects will be". Hence, COVID-19 is a battle; it is a war that all nations must come together to fight earnestly.

\section{Killer (Disease)}

COVID-19 is represented as a killer - something that terminates or ends the life of another. Any potential killer is perceived as a criminal. The lexical item 
'kill' is used by the newspapers to represent COVID-19 as a killer (with 6\% of the identified representations) as exemplified in texts 16-18.

(16) Covid-19, the disease caused by this new virus, appears to be between seven and 20 times more deadly than seasonal flu, which on average kills between 300,000 and 650,000 people globally each year. But that fatality rate could prove to be much lower, especially if it turns out that many milder cases have evaded detection (NYT, February 29, 2020).

(17) The Guardian view on the Covid-19 strategy: insuring against a killer (The Guardian, March 31, 2020).

(18) However, while the world may have witnessed many wars and outbreaks of killer diseases, the Covid-19 has presented a challenge unlike any other before (The Punch, March 20, 2020).

The representation of anything or anyone as a killer implicates criminalisation and or demonisation. Texts 16-18 lexicalise, criminalise and demonise COVID-19 as a killer using lexical items such as "kill", "deadly", "fatality", and "killer". To underscore the representation of COVID-19 as a killer disease the discourse structures actor description, evidentiality, lexicalisation and burden are deployed. Texts 16 gives a further description of the virus, using evidential figures 300,000 650,000 of minimum potential victims of other COVID-19-related viruses as the basis for argument, thereby criminalising and demonising COVID-19 to emphasise that the earlier everyone is conscious of the potential evil of the virus the better. Meanwhile text 17 only warns all on the need to be insured "against a killer". Text 18 also activates the use of Burden and Comparison to argue that COVID-19 cannot be compared with other "outbreaks of killer diseases", and argue that all should consciously see COVID-19 as a "challenge unlike any other before." Hence, everyone needs to be conscious of the "killer".

\section{Plague}

The newspapers also represent COVID-19 as a plague (4\% representation). A plague is a disastrous evil or affliction or an epidemic disease causing a high rate of mortality, and has characterised COVID-19 already reported to have claimed numerous lives.

(19) We've been down this road before, too many times. In the $14^{\text {th }}$ century the Black Death provoked mass violence against Jews, Catalans, clerics and beggars; when syphilis spread in the $15^{\text {th }}$ century, it was called variously the Neapolitan, French, Polish and German disease, depending on who was pointing the blame; when the plague struck Honolulu in 1899, officials burned down Chinatown. And so on, down to our times, when epidemics like Ebola, SARS and Zika fueled animus toward specific regions or peoples. Here we are in 2020, with Asians being assailed across the United States and around the world as purported sources of the "Chinese flu", the "Wuhan coronavirus" or simply the "foreign virus". Once again, a mysterious, fast- 
spreading and sometimes lethal disease is exacerbating racism and hatred - only now with the help of the potent megaphone of social media. (NYT, March 23, 2020).

(20) Not much is known about COVID-19 as experts are still gathering information about the virus. All hands should be at the plough; apart from mobilising all health professionals like Lagos and many countries who have recalled retired care givers, student doctors and other volunteers, other states and the government should follow and mobilise all segments of the society to confront this plague (The Punch, March 24, 2020).

The representation of COVID-19 as a plague is very close to its representation as a pandemic or epidemic. However, the choice of the word "plague" resonates more with Christians or Bible scholars who are more conscious of the dastardly effect of a plague. This representation is therefore both informational and a plea for them to swing into action. The representation was only projected by NYT and The Punch newspapers. Text 19 commences with the use of historical reference as Burden, Evidentiality and Comparison to substantiate the argument and represent what similar plagues had done in the past, comparing them with COVID-19 and establishing the view that they share "plagueness" in common. Hence, COVID-19, as a "plague" that it is, is a "fast-spreading and sometimes lethal disease". Text 20 only makes reference to COVID-19 requesting all hands to be on the deck "to confront this plague".

\section{(Man's) Common Enemy}

An enemy is someone that is antagonistic to another or who seeks the other's injury. Enemy (3\%) representation has been used to describe COVID-19.

(21) Boris Johnson's declaration of war on an invisible, elusive and advancing foe was long overdue (The Guardian, March 24, 2020).

(22) The virus is a common foe (China Daily, March 18, 2020).

Only The Guardian and China Daily have used "enemy or foe" to refer to COVID-19. The portrayal of COVID-19 as a man's common enemy underscores the fact that COVID-19 is a cog in the wheel of man's progress. The use of "common" underlines the need for man to come together in unison to combat the virus that is seeking the injury or fall of all. Meanwhile, text 21 still uses a subtle reprimand to allege that the British Prime Minister, Boris Johnson should have declared the virus as an enemy earlier than has just been done.

Fire

Fire, which is a severe trial or ordeal, controls $2 \%$ of the total representations. COVID-19 is also represented as fire.

(23) Here Comes the Coronavirus Pandemic: Now, after many fire drills, the world may be facing a real fire (NYT, February 29, 2020). 
(24) There is still a chance that Covid-19 will prove to be more fire drill than actual fire (NYT, February 29, 2020).

The representation of COVID-19 as fire is only found in NYT. Using the discourse structure, Comparison, texts 19 and 20 compare between fire drill and a real fire or actual fire. In essence, COVID-19 is metaphorically represented as not just a fire but the real fire or actual fire that all need to be wary of. This representation of COVID-19 as a severe trial or ordeal demonises COVID-19 and calls all to action.

\section{Disaster}

Disaster - a sudden misfortune bringing great damage, loss, or destruction has been correlated with COVID-19 in the newspapers. The representation of COVID-19 as a disaster is one of the least (2\%) representations as exemplified in text 25 .

(25) For those already suffering from war and other disasters, the prospect of the worst is almost unthinkable (The Guardian, March 17, 2020).

Again, only The Guardian newspaper conceives COVID-19 as a disaster. To the editor, if the people and the government see COVID-19 as a disaster, they will be more cognizant of the need to deal with it headlong. Text 25 uses Comparison to canvass that the impending disaster of COVID-19 is worse compared with war and other disasters. The other disasters are small compared with the misfortune, damage and destruction that COVID-19 is set to unleash.

\section{Representations and Participants: Implications}

COVID-19 has been variously represented as outbreak, pandemic, economic cankerworm, threat to humans, war, killer, plague, common enemy, fire and disaster. Different intentions subsist for the various representations. The central motive behind the various representations is to cognitively task the readers and the masses in general about the potential evil of COVID-19. COVID-19 is embodied as a disease that: spreads suddenly; spreads over a whole country or the whole world; affects people's behaviour; inflicts evil, injury, or damage to humans; weakens or destroys humans; terminates the life of its victims; causes a high rate of mortality; seeks human's injury; burns to death; and brings great damage, loss, or destruction. These various representations converge to demonise and criminalise COVID-19. Therefore, this is an invitation to humans (discursively referred to as participants) to swing into action, assume different positions and roles to confront the "demon" and "criminal".

Three different types of participants therefore evolve from the discourse. The participants include the state/health professionals, non-carriers of COVID-19 and carriers of COVID-19. The representations put the state (government) and the health professionals in the position of authority to come together to solve the 
problem already created by the onset of the virus, while the carriers and noncarriers are expected to obey the directives given by the government as advised by the health practitioners and professionals.

The different representations given to COVID-19 in the newspapers have diverse physical and psychological implications and intentions. The representations have a converging appeal to the cognitive, affective and psycho-motor domains of participants, conveying the need for unanimity by the three participants for success to be ascertained. The various representations further underscores the need: to battle the pandemic earnestly; for all to be wary of their actions in order to contain and curtail the spread of the virus; that all should behold the looming disaster if there is no cooperation to clip the pandemic from truncating the economy; to tackle the disease before it tackles humans.

The state and health practitioners are represented as the major solvers of the virus, while the health practitioners are represented as the carers. The state is expected to lock down and enforce lockdown to contain the spread, provide hospitals and other equipment like ventilators to treat carriers, create isolation centres for carriers, provide stimulus or palliatives to cushion the effect on the citizens, and so forth. The state is also expected to collaborate with the health professionals to massively test citizens, treat carriers, trace contact and research on vaccine. The editorials consistently deploy ideological discourse structures like Authority, Burden, Evidentiality and Comparison to refer to countries that have made a remarkable progress based on harmonious confrontation of the virus, as evident in text 26.

(26) But there is no question that the W.H.O.'s approach works better. Every region that has managed to get a coronavirus outbreak under control has succeeded thanks to a combination of social distancing and aggressive efforts to test as many people as possible. South Korea, for example, has tested some 274,000 people since February. The United States has tested just 82,000, the vast majority of them in the past few weeks (NYT, March 24, 2020).

In text 26, NYT uses W.H.O. as the authority to support its position, using both Burden and Evidentiality to argue out its position and citing the experience with South Korea as a ground, example and Illustration for America and others to follow in a bit to combat the pandemic. While this is a sort of call to action to the state, it is equally a condemnation strategy to query their lethargic pace in following the working example of South Korea. This also suggests to (potential) carriers the need for self-guard.

(27) But it takes political decisiveness to lock down a city or area. And it takes doctors, nurses, sickbeds, testing kits, breathing machines, medical oxygen, plus large amounts of disinfectant, surgical masks, protective overalls and goggles each day, to give purpose to the lockdown (China Daily, March 26, 2020).

(28) Around the world, authorities are being forced to make difficult and complex decisions in this crisis. Mass quarantines of the kinds seen in Wuhan, China and Italy, may not be the only or even the best approach; it appears aggressive testing and contact tracing with some social distancing measures have been effective in countries 
including Singapore and South Korea (which has been testing 20,000 people a day) (The Guardian, March 12, 2020).

Texts 27 and 28 also suggest other roles expected of the state, including lockdown, contact tracing, aggressive testing of the citizens, citing the example of Wuhan, China as the approach which assisted in timely containment. Although the total or partial lockdown has its attendant negative consequence, including economic stagnancy, economic melt-down, occupational denial, hijack of jobs, denial of freedom, house arrest and so forth, it is better off for early containment on the long run. Text 29 also suggests that all the participant-roles will not really be as effective as discovering a vaccine that will ultimately help to solve the problem. Of course, this is a role expected of health professionals, which also relies on funding by the state.

(29) No matter how effective wearing face masks, washing hands, self-quarantining and social distancing are in preventing people from being infected with the novel coronavirus, a vaccine will ultimately be the most effective solution (China Daily, March 18, 2020).

The non-carriers are represented as potential victims and spreaders of COVID-19.The non-carriers, who are potential victims and spreaders, are expected to abide by the directives of the government and health practitioners. Hence, they are required to collaborate with the state in distancing socially (spatially); disinfecting surfaces around; maintaining healthy lifestyle by consuming healthy food, engaging in regular exercise and sleeping well; coughing or sneezing into bent elbow; disposing of used tissue; washing hands with soap \& running water; sanitising one's hands regularly; protecting self \& others against droplets; not touching mouth, nose, and eyes; wearing nose/protective mask; staying home/safe; not panicking and consuming immunity boosters, as evidently expressed in samples 30 and 31 .

(30) No matter how effective wearing face masks, washing hands, self-quarantining and social distancing are in preventing people from being infected with the novel coronavirus, a vaccine will ultimately be the most effective solution. That explains why President Xi Jinping emphasised the importance of science and technology in the fight against the virus in a signed article published in Qiushi Magazine on Monday (China Daily, March 18, 2020).

(31) Since coronavirus has no known cure, prevention remains the best form of defence. A highly contagious disease, people have been warned to stay away from crowded places and to avoid unnecessary contact. The United States Centres for Disease Control and Prevention says the best protection is to wash hands often with soap and water for at least 20 seconds. People have also been advised to keep a distance from sick people and to "avoid touching your eyes, nose or mouth with unwashed hands". When coughing, tissues should be used to cover one's mouth. It is expected that most people who suffer from coronavirus may eventually recover on their own; but the CDC advises that the symptoms should be treated. Those mildly 
sick are advised to drink a lot of liquid and observe adequate rest (The Punch, January 30, 2020).

The emphasis on social distancing has to do with a reduction in or totally stopping physical contacts with others. Socialisation has to do with societal or communal involvement of a people. It could also relate to interactants in a social sect. The editorials deploy ideological discourse structures like Authority to represent the virus as anti-social. The activation of social distancing among all humans as authorised by the WHO indexes COVID-19 as anti-socialisation, that is a breaker of socialisation. Although Abel and McQueen (2020) query the correctness and grammaticality of "social distancing", and suggest "spatial distancing" in its place, the concept of distancing is still of essence. Of course I agree with the stance of Abel and McQueen that we need to project more of spatial distancing than "social" since communication via the phone and other nonphysical means can still be termed "social". Even this discoursal incongruity has been further spread and projected by the W.H.O., represented in text 32 thus:

(32) The World Health Organization, for weeks now, has been making an emphatic plea to countries around the world: Social distancing is crucial to stopping the spread of coronavirus (NYT, March 19, 2020).

The actual carriers, whose cases may be mild or non-mild, are the real spreaders of COVID-19. While the mild carriers, also referred to as asymptomatic carriers, may not immediately display symptoms, the non-mild carriers display symptoms within the first and fourteenth day of having contact with a carrier or (super-)spreader.

(33) Symptoms, according to the World Health Organisation, include fever, cough, shortness of breath and breathing difficulties. In severe cases, it could lead to pneumonia, SARS, kidney failure and death (The Punch, January 30, 2020).

As spelt out in text 33 and others, and as authorised by the WHO, some of the symptoms of COVID-19 are itchy/dry throat, dry cough, high temperature, fever, fatigue, body aches, shortness of breath, loss of smell/taste, and so forth. Carriers are therefore expected to collaborate with the state to isolate from others, cooperate with carers, consume immunity boosters, and so forth.

\section{Conclusion}

This study on COVID-19 set out to examine selected newspaper editorials across four continents/countries in the world in order to identify how the virus and associated participants are represented in newspapers globally. The analysis was guided by aspects of van Dijk's (2006c) socio-cognitive model of critical discourse analysis on ideological discourse structures. The selected COVID-19-related editorials of newspapers (New York Times, The Guardian, China Daily and The Punch) which cut across the USA in North America, the UK in Europe, China in 
Asia and Nigeria in Africa were subjected to quantitative and discourse analyses. The newspapers largely set the agenda on the negative representation of the disease and its potential havoc on all facets of human endeavours, thereby giving emotional and informational appeal to all to join hands in earnestly silencing the epidemic.

The study revealed that the newspaper editorials unusually converged to negatively represent an issue - COVID-19 - because it is largely negatively viewed by all. The newspaper editorials variously represented COVID-19, using ten representational strategies: outbreak, pandemic, economic cankerworm, threat to humans, war, killer (disease), plague, common enemy, fire and disaster. Different intentions subsist for the various representations, just as differences are observed in the newspaper representations. All the newspapers converge to represent COVID-19 as outbreak, pandemic, economic cankerworm, threat to humans and war; whereas there were observed differences in the representations of COVID-19 as killer (disease), plague, common enemy, fire and disaster. The representation as plague was only projected by NYT and The Punch newspapers; the representation as man's common enemy was only used by The Guardian and China Daily; only NYT represented COVID-19 as fire; and only The Guardian newspaper conceives COVID-19 as a disaster.

The representational strategies were developed by the newspapers with six discourse strategies, including demonising the disease, criminalising the disease, calling the state to action, emotional and informational appeal to the masses, condemnation of the state, and historical reference. To the reader's cognition, therefore, the implication is that of consciousness on the evil effect of COVID-19 and the need to cooperate with the state and health workers to checkmate its evolution. Consequently, the represented human participants have different roles to play in safeguarding the globe. While the state and health professionals are represented as major problem-solvers and carers, the (non-)carriers are represented as (potential) victims and or (super) spreaders who must perform different containment roles, including social distancing (preferably, spatial/physical distancing); staying at home to stay safe from the virus; wearing a nose/mouth mask; keeping clean hands with soap and alcohol-based sanitizer regularly; sneezing or coughing into a flexed elbow or a disposable towel; avoiding touching of the face, especially mouth, eyes, and nose; avoiding touching surfaces, among others in order to collectively combat the virus. Both the COVID-19 and human representational strategies were also reinforced through the deployment of twelve ideological discourse structures: actor description, authority, burden, comparison, evidentiality, illustration, generalisation, lexicalisation, metaphor, negative otherpresentation, norm expression and number game.

Therefore, this paper argues that the reporters and the newspapers, whose mental models have already been formed by the implicit and explicit information on COVID-19, establish the agenda by positioning their readers' cognition to negatively perceive coronavirus (COVID-19). The ten representations give adherence to the agenda-setting prowess of the media. The negative portrayal, demonising and criminalising COVID-19, alongside other constructions, as identified with the discourse tools, goes a long way in creating a cognitive 
awareness in the minds of the citizenry, bringing consciousness to the readers on the negative capability and destructive strength of the life-threatening disease.

\section{References}

Abel, T., McQueen, D. (2020). Editorial: the COVID-19 pandemic calls for spatial distancing and social closeness: not for social distancing! International Journal of Public Health, 65(3), 231.

Baehr, P. (2006). Susan Sontag, battle language and the Hong Kong SARS outbreak of 2003. Economy and Society 35(1), 42-64.

Barry, J. H. (2005). 1918 Revisited: lessons and suggestions for further inquiry. In S. L. Knobler et al. (eds.), The Threat of Pandemic Influenza: Are We Ready? 58-68. Washington DC: National Academies Press.

Chen, S. (2005). Whence Cometh SARS: a short description of a pattern of inter-cultural contacts and related discourses in Taiwan. In Proceedings of the $8^{\text {th }}$ 1ASS Congress IASS and Univ-Lyon, 1-9.

Chiang, W., Duann, R. (2007). Conceptual metaphors for SARS: 'war' between whom? Discourse \& Society, 18(5), 579-602.

Chiluwa, I., Odebunmi, A. (2016). On terrorist attacks in Nigeria: stance and engagement in conversations on Nairaland. Communication and the Public, 1(1), 91-109.

Eagleton, J. (2004). SARS: "It's as bad as we feared but dared not say". English Today, 20(1), 34-45.

Fairclough, N. (1995). Critical discourse analysis: the critical study of language. London: Longman.

Larson, B. M. H., Nerlich, B., Wallis, P. (2005). Metaphors and biorisks: the war on infectious diseases and invasive species. Science Communication, 26(3), 243-268.

Mahdi, Y. (2009). A critical discourse analysis of selected Iranian and American printed media on the representation of the Hizbullah-Isreal war. Retrieved from: http://www. immi.se/intercultural/. [Accessed 24 January 2014]

Majid, K. (2008). British newspapers and the representation of refugees, asylum seekers and immigrants between 1996 and 2006. Working Paper Series: Centre for Learning and Social Life, 128(3), 44-62.

Osisanwo, A. A. (2011). Language and ideology in news magazine's representation of Nigeria's 2003 and 2007 general elections. PhD Thesis. Ibadan, Nigeria: Department of English, University of Ibadan.

Osisanwo, A. A. (2016a). Discursive representation of Boko Haram terrorism in selected Nigerian newspapers. Discourse and Communication, 10(4), 341-362.

Osisanwo, A. A. (2016b). Role allocation in the media representation of participants in selected electoral discourses in Nigeria. Athens Journal of Mass Media and Communications, 2(3), 183-204.

Osisanwo, A. A. (2017a). Linguistic features of news reports of war on terrorism in Nigeria. Ife Studies in English Linguistics, 13(2), 57-82.

Osisanwo, A. A. (2017b). Stance and engagement in e-punch newspaper readers' comments on former President Goodluck Jonathan administration's war against Boko Haram terrorism in Nigeria. Journal of English Studies Association of Nigeria, 19(1), $143-160$.

Osisanwo, A. A. (2019). Blame-frame and praise-frame on the Boko Haram terrorism in Nigeria newspapers: a discourse examination. PEOPLE: International Journal of Social Sciences, 4(3), 1633-1651. 
Osisanwo, A. A., Oluwayemi, V. (2018). Divorce as conflict: representation of participants in selected Nigerian newspaper reports on divorce cases. Ibadan Journal of Humanistic Studies, 28(1): 91-108.

Oyeleye, L., Osisanwo, A. A. (2013a). Lexicalisation in media representation of the 2003 and 2007 general elections in Nigeria. World Journal of English Language, 3(2), 1-9.

Oyeleye, L., Osisanwo, A. A. (2013b). Expression of ideologies in the media representation of the 2003 and 2007 general elections in Nigeria. Discourse \& Society, 24(6), 763773.

Potter, C. W. (2001). A History of Influenza. Journal of Applied Microbiology, 91(4), 572-579.

Talaat, P. (2011). Islamists in the headlines: critical discourse analysis of the representation of the muslim brotherhood in Egyptian newspapers. PhD Thesis. Utah, USA: Department of languages and literature. Arts, University of Utah.

Trčková, D. (2015). Representations of natural catastrophes in newspaper discourse. Brno: Masaryk University.

van Dijk, T. (2001a). Discourse, ideology and context. Folia Linguistica, XXXV(1-2), 1140.

van Dijk, T. (2001b). Multidisciplinary CDA: a plea for diversity. In R. Wodak, M. Meyer (eds.), Methods of Critical Discourse Analysis, 95-120. London: Sage Publications.

van Dijk, T. (2006a). Introduction: discourse, interaction and cognition. Discourse Studies, $8(1), 5-7$.

van Dijk, T. (2006b). Discourse and manipulation. Discourse \& Society, 17(2), 359-383.

van Dijk, T.A. (2006c). Politics, ideology and discourse. Barcelona: Elsevier Services.

Wallis, P., Nerlich, B. (2005). Disease metaphors in new epidemics: the UK media framing of the 2003 SARS epidemic. Social Science and Medicine, 60(11), 2629-2639.

Washer, P. (2004). Representations of SARS in the British newspapers. Social Science \& Medicine, 59(12), 2561-2571.

Wodak, R. (2002). Aspect of critical discourse analysis. ZFAL 36, 5-31. 